\title{
CHRONOLOGY OF A FORTIFIED MISSISSIPPIAN VILLAGE IN THE CENTRAL ILLINOIS RIVER VALLEY
}

\author{
Anthony M. Krus ${ }^{1,2}$, Edward W. Herrmann ${ }^{3}$, Matthew D. Pike ${ }^{4}$, G. William Monaghan ${ }^{5}$, \\ Jeremy J. Wilson ${ }^{5}$ \\ ${ }^{1}$ University of Glasgow, SUERC, Scottish Enterprise Technology Park, Rankine Avenue East \\ Kilbride G75 0QF, Scotland, United Kingdom. Corresponding author. Email: \\ tony.krus@glasgow.ac.uk \\ ${ }^{2}$ Department of Anthropology and Sociology, University of South Dakota, Vermillion, SD, \\ 57069 \\ ${ }^{3}$ Indiana University, Department of Earth and Atmospheric Sciences, 1001 East 10th Street, \\ Bloomington, IN 47405-1405 \\ ${ }^{4}$ Purdue University, Department of Anthropology, 700 W. State Street, Suite 219 \\ West Lafayette, IN 47907-2059 \\ ${ }^{5}$ Indiana University-Purdue University Indianapolis, Department of Anthropology, 425 \\ University Boulevard, Indianapolis, IN 46202-5140
}

\begin{abstract}
Geophysical survey and excavations from 2010-2016 at Lawrenz Gun Club (11CS4), a late pre-Columbian village located in the central Illinois River valley in Illinois, identified 10 mounds, a central plaza, and dozens of structures enclosed within a stout 10 hectare bastioned palisade. Nineteen radiocarbon measurements were taken from single entities of wood charcoal, short-lived plants, and animal bones. A site chronology has been constructed using a Bayesian approach that considers the stratigraphic contexts and feature formation processes. The village was host to hundreds of years of continuous human activity during the Mississippi Period. Mississippian activity at the site is estimated to have begun in cal AD 990-1165 (95\% probability), ended in cal AD 1295-1450 (95\% probability), and lasted 150 $420 y r(95 \%$ probability) in the primary Bayesian model with similar results obtained in two alternative models. The palisade is estimated to have been constructed in cal AD 1150-1230 (95\% probability) and was continuously repaired and rebuilt for $15-125 \mathrm{yr}(95 \%$ probability), probably for 40-85 yr (68\% probability). Comparison to other studies demonstrates that the bastioned palisade at Lawrenz was one of the earliest constructed in the midcontinental U.S.
\end{abstract}

\section{KEYWORDS}

Bayesian modeling; Late Woodland Period; Mississippi Period; Central Illinois River Valley; Warfare

\section{INTRODUCTION}

Deciphering the chronology of Native American occupation has been an important component of archaeological research in the midcontinental United States (U.S.) for more than a century. Evidence of human presence in the region spans approximately 15,000 years, and at many sites, multiple discrete occupations complicate our ability to resolve occupational chronologies. Stratigraphic relationships between diagnostic artifacts and site features associated with multiple occupations provide a relative framework for ordering the sequence of events that occurred at a site. However, archaeologists working in the 
midcontinental U.S. have long struggled with accurately and precisely deciphering the timing of ancient activity at settlements that span the Late Woodland and Mississippi Period boundaries (AD 250-1000 and AD 1000-1500, respectively).

In this paper, we report the results of radiocarbon $\left({ }^{14} \mathrm{C}\right)$ dating and Bayesian chronological modeling from Lawrenz Gun Club (11CS4), a major fortified village located in the central Illinois River valley (CIRV) in west-central Illinois that was occupied during the Late Woodland and Mississippi Periods (Figure 1). Bayesian chronological modeling is increasingly applied to provide probabilistic chronological frameworks that help decipher the timing and duration of occupations at individual archaeological sites (Bayliss 2015; Hamilton and Krus 2018). Likewise, Bayesian techniques can also provide high-precision chronologies at robustly dated midcontinental U.S. archaeological sites with multiple episodes of occupation (e.g., Krus et al. 2015; Thompson and Krus 2018).

A relative chronology for late pre-Columbian occupation in the CIRV was established by Harn $(1975 ; 1994)$ and Conrad (1991) using artifact typologies and stratigraphic associations at dozens of sites and calibrated ${ }^{14} \mathrm{C}$ dates from five sites. Most archaeological work in the CIRV has primarily relied upon relative dating techniques (e.g., ceramic seriation) as a means of defining temporal relationships between sites. While ${ }^{14} \mathrm{C}$ dates from mounds and habitations in the CIRV have indicated that mound building began during the Woodland Period and that larger settlements were present along the banks of the Illinois River by the Late Woodland Period (Conner 2016; Esarey 2000; Green and Nolan 2000; Hart et al. 2002; Holt 2005; Holt and Feathers 2003), archaeological chronologies have traditionally been interpreted as a series of discrete Woodland and Mississippi Period cultural phases (Conrad 1991; Conrad and Harn 1972; Esarey and Conrad 1998). Relatively few ${ }^{14} \mathrm{C}$ dates have been obtained and Wilson (2010:51) recently noted that the paucity of ${ }^{14} \mathrm{C}$ dates from the CIRV has resulted in "insufficient knowledge" about Woodland/Mississippi transitional period sites. More recently, Wilson et al. (2018) analyze 24 new ${ }^{14} \mathrm{C}$ dates from Mississippian CIRV occupations with exploratory Bayesian models for ceramic chronologies, but do not fully consider sample taphonomy in their modeling, nor derive definitive conclusions from the Bayesian models in part due to the paucity of ${ }^{14} \mathrm{C}$ data.

Lawrenz Gun Club is the largest Mississippi Period village in the CIRV, abutting the Little Sangamon River approximately $7 \mathrm{~km}$ south-southeast of its confluence with the Illinois River. Archaeological, geophysical, and geoarchaeological investigations between 2010 and 2016 focused on the site's chronology, internal organization, and fortifications. Lawrenz has a minimum of 10 mounds, a central plaza, and dozens of structures enclosed within a stout ca. 10 hectare palisade with bastions (Figure 1) (Wilson and Pike 2015). Dozens of additional structures have been detected through magnetic gradiometry and structures exist outside the village's walls to the north and south. This includes a series of smaller, wall-trench structures associated with the establishment of the community in the late $11^{\text {th }}$ century AD. Although only a small portion of the site (less than 0.5 percent) has been excavated, we have recovered enough evidence from palisade construction episodes, one mound, a paleochannel, and structures both inside and outside the palisade to provide a chronology for the main period of site occupation. 


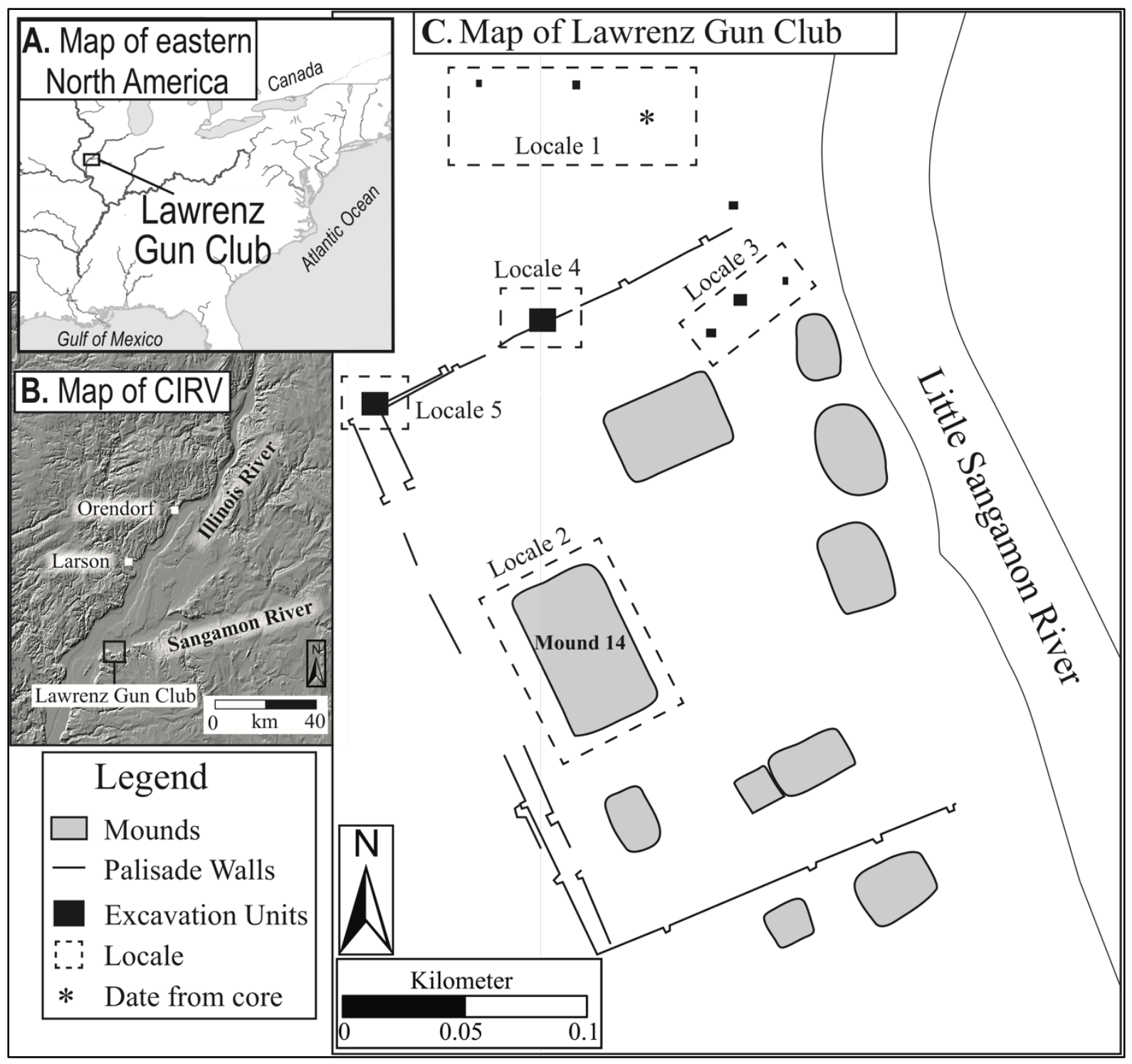

Figure 1: Lawrenz Gun Club Village map. 
Table $1 .{ }^{14} \mathrm{C}$ data for the Lawrenz Gun Club

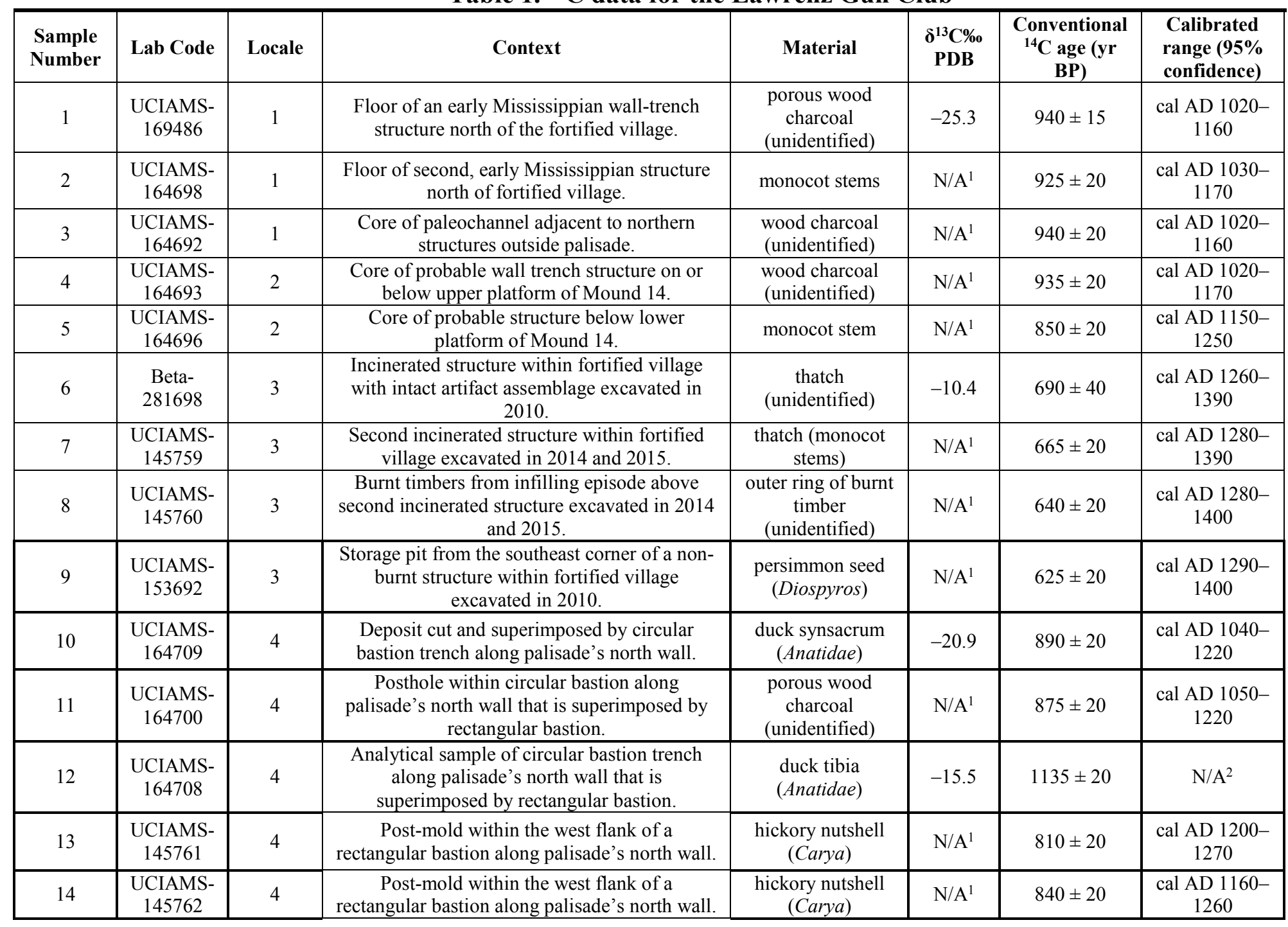




\begin{tabular}{|c|c|c|c|c|c|c|c|}
\hline 15 & $\begin{array}{l}\text { UCIAMS- } \\
145763\end{array}$ & 4 & $\begin{array}{l}\text { Base of the west flank of a rectangular bastion } \\
\text { trench along palisade's north wall; possible } \\
\text { bottom of a large burnt post. }\end{array}$ & $\begin{array}{l}\text { willow/poplar } \\
\text { wood charcoal }\end{array}$ & $\mathrm{N} / \mathrm{A}^{1}$ & $805 \pm 20$ & $\begin{array}{c}\text { cal AD } 1200- \\
1270\end{array}$ \\
\hline 16 & $\begin{array}{c}\text { UCIAMS- } \\
164694\end{array}$ & 4 & $\begin{array}{c}\text { Burnt, rectangular deposit immediately } \\
\text { northeast of rectangular bastion superimposing } \\
\text { a circular bastion along the palisade's north } \\
\text { wall. }\end{array}$ & $\begin{array}{l}\text { cucurbit rind } \\
\text { (Cucurbitaceae) }\end{array}$ & $\mathrm{N} / \mathrm{A}^{1}$ & $845 \pm 20$ & $\begin{array}{c}\text { cal AD } 1160- \\
1260\end{array}$ \\
\hline 17 & $\begin{array}{l}\text { UCIAMS- } \\
164697\end{array}$ & 5 & $\begin{array}{l}\text { First (southern) iteration of a circular bastion } \\
\text { trench on the northwest corner of the fortified } \\
\text { village. }\end{array}$ & $\begin{array}{c}\text { willow/poplar } \\
\text { (Salicaceae) wood } \\
\text { charcoal }\end{array}$ & $\mathrm{N} / \mathrm{A}^{1}$ & $830 \pm 20$ & $\begin{array}{c}\text { cal AD } 1160- \\
1260\end{array}$ \\
\hline 19 & $\begin{array}{l}\text { UCIAMS- } \\
164699\end{array}$ & 5 & $\begin{array}{l}\text { Analytical sample of burnt layer from collapse } \\
\text { of the circular-bastioned palisade on the } \\
\text { northwest corner of the fortified village. }\end{array}$ & $\begin{array}{l}\text { red/white oak } \\
\text { wood charcoal } \\
\text { (Quercus) }\end{array}$ & $\mathrm{N} / \mathrm{A}^{1}$ & $830 \pm 20$ & $\begin{array}{c}\text { cal AD } 1160- \\
1260\end{array}$ \\
\hline
\end{tabular}

${ }^{1} \delta^{13} \mathrm{C}$ was not measured on fifteen of the UCIAMS dates.

${ }^{2}$ The $\delta^{13} \mathrm{C}$ value (-15.5\%) derived from AMS for UCIAMS-164708 suggests the presence of an unknown marine component in the diet of this sample. A $\delta^{13} \mathrm{C}$ value derived from a subsample of the pretreated bone would further allow for the estimation of the percentage of diet from terrestrial/marine

resources, but this is not available. Therefore, this sample has not been subjected to ${ }^{14} \mathrm{C}$ calibration or Bayesian chronological modeling. 
Research at Lawrenz has been part of a National Science Foundation Research Experience for Undergraduates (SMA 1262530) program concentrating on chronological and stratigraphic relationships of remotely sensed and sampled archaeological features. We initially identified near surface (30-130 cm deep) features associated with the main ceremonial mound complex and plaza area using a Bartington Grad601-2 magnetic gradiometer (Wilson and Pike 2015). This survey revealed that the main portion of the site was enclosed by multiple iterations of a wall-trench, palisade fortification, as well as numerous domestic and special-purpose structures with wall-trench foundations and interior basins both inside and outside the palisade. Using the gradiometer map and signal strength to guide our research (Figure 1), we chose to excavate apparent structures located inside and outside the palisade, and portions of the palisade itself. Because the palisade's west wall exhibits three different major construction episodes, we excavated the northwest corner of the inner palisade where the palisade trenches crosscut one another to decipher stratigraphic relationships, recognizing the potential to utilize a Bayesian framework in conjunction with the ${ }^{14} \mathrm{C}$ measurements from sequential deposits (Figure 2). A second series of test units were placed along the palisade's north wall where two major construction episodes were revealed during remote sensing, including a rectangular bastion that superimposes a previously constructed circular bastion (Figure 2). The mounds, structures, and other features within the fortified village were all associated with Mississippian artifacts believed to date to the mid-12 ${ }^{\text {th }}$ to early $14^{\text {th }}$ centuries AD. Low quantities of Woodland artifacts recovered during pedestrian survey allude to the existence of a small Woodland component prior to Mississippi Period village formation.

Advances in the statistical modeling of ${ }^{14} \mathrm{C}$ dates and archaeological data within Bayesian frameworks allow researchers to understand site chronologies better and even produce ${ }^{14} \mathrm{C}$ estimates accurate to the level of a human generation (Bayliss 2009; 2015; Bayliss et al. 2007; 2011). At Lawrenz, questions of site establishment, use, and abandonment are at the forefront of archaeological investigations. Probabilistic estimates derived from Bayesian modeling for the timing of activity at Lawrenz can be used to address these seminal research questions directly. Such modeling not only uses the absolute dating provided by the ${ }^{14} \mathrm{C}$ measurements, but also the relative relationships provided by stratigraphy and feature groupings.

\section{RADIOCARBON SAMPLING}

Samples from archaeological and geological contexts were submitted for accelerator mass spectrometry (AMS) ${ }^{14} \mathrm{C}$ dating to Beta Analytic and the W.M. Keck Carbon Cycle Accelerator Mass Spectrometer facility (KCCAMS) at the University of California, Irvine. Eighteen single-entity (Ashmore 1999) samples of animal bone, short-lived plants, nutshell, thatch, and wood charcoal were submitted to KCCAMS. A single-entity sample of thatch was submitted to Beta Analytic.

The pretreatment protocols for these samples can be found on the Beta Analytic (see http://www.radiocarbon.com) and KCCAMS (see http://www.ess.uci.edu/researchgrp/ams/protocols) websites. Both labs maintain rigorous internal quality assurance procedures, and participation 
in international inter-comparisons (Scott et al. 2003; 2007; 2010) indicates no laboratory offsets; thus, validating the measurement precision quoted for the ${ }^{14} \mathrm{C}$ ages.

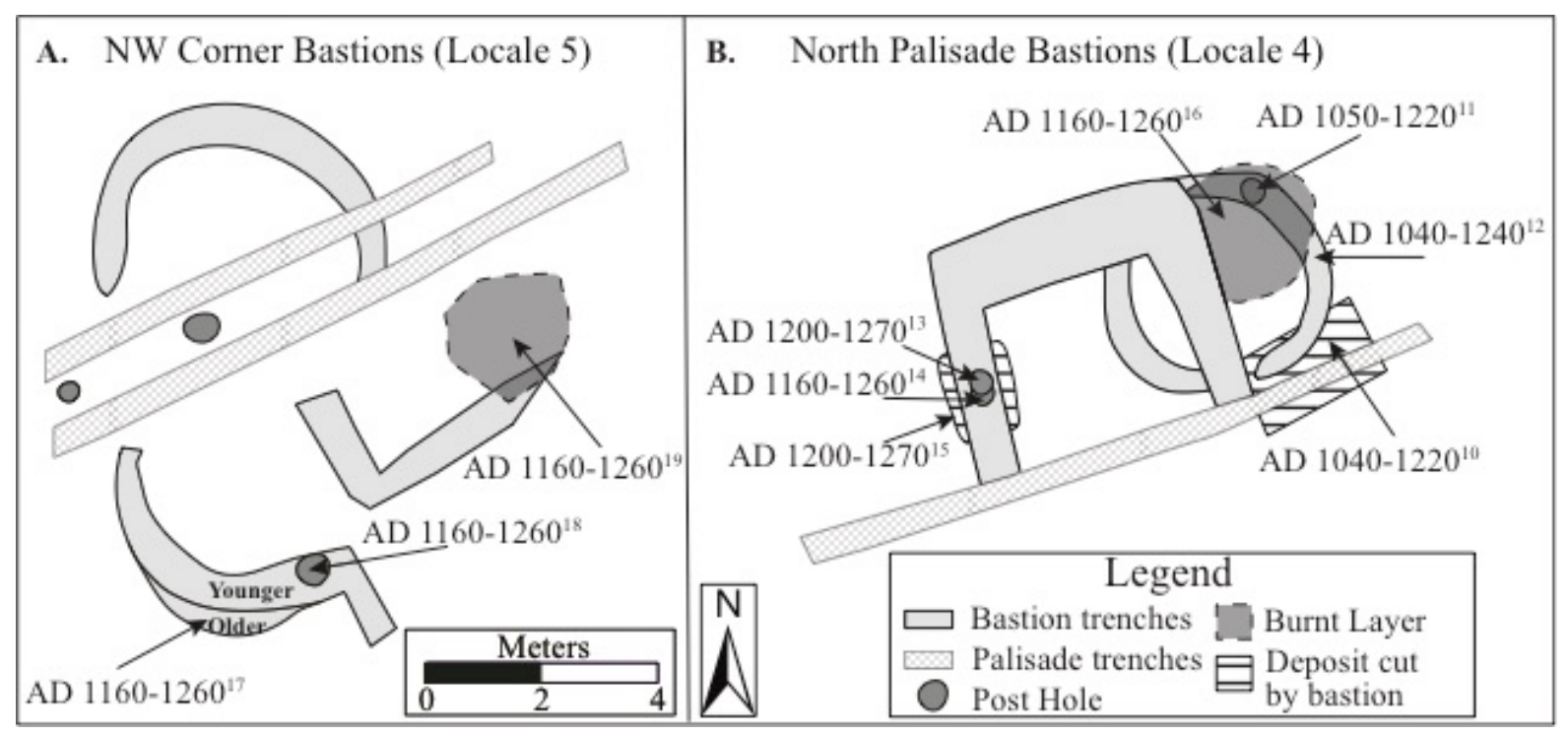

Figure 2: Map of Locales 4 and 5 in Figure 1 showing the crosscutting relationships between the archaeological contexts and the locations of the ${ }^{14} \mathrm{C}$ samples. Calibrated ranges and superscript sample numbers are provided for each ${ }^{14} \mathrm{C}$ date.

The results of the ${ }^{14} \mathrm{C}$ determinations are presented in Table 1, where they are quoted in accordance with the Trondheim Convention (Stuiver and Kra 1986) as conventional ${ }^{14} \mathrm{C}$ ages (Stuiver and Polach 1977). Calibrated date ranges were calculated using the IntCal13 calibration curve of Reimer et al. (2013) and OxCal v4.3. Calibrations are cited in the text as 95\% confidence intervals, with the end points rounded outwards to 10 years.

\section{METHODOLOGY}


The technique used for Bayesian chronological modeling is a form of Markov Chain Monte Carlo sampling (Buck et al. 1991; 1996) and has been applied using the program OxCal v4.3 (http://c14.arch.ox.ac.uk/). Details of the algorithms employed by OxCal v4.3 are available in Bronk Ramsey $(1995 ; 1998 ; 2001 ; 2009 a)$ or from the online manual (see http://c14.arch.ox.ac.uk/oxcalhelp/hlp contents.html). The fit between the OxCal model and data is gauged with the $\mathrm{A}_{\text {model }}$ agreement index and values higher than 60 indicate good agreement between the model parameters and the dates (Bronk Ramsey 1995). Resulting posterior density estimates from OxCal are calendar years and presented in italics as probability ranges with end points rounded to the nearest five years. The algorithms used in the models can be derived from the OxCal keywords and bracket structure shown in the probability distribution plots (Figures 3-7). Key posterior probabilities for chronological estimates from the models are also summarized in Tables $2-3$. The posterior density estimates produced by modeling are not absolute and are interpretative estimates that may change as further data become available or as other researchers choose to model the existing data from different perspectives.

\section{THE SAMPLES AND MODEL}

Geophysical and archaeological evidence suggests that the palisade at Lawrenz was subjected to extensive modification throughout the settlement's history, including a shift from circular to rectangular bastions. Nine contexts associated with different sections of the palisade and individual bastions were sampled for ${ }^{14} \mathrm{C}$ dating (Wilson and Pike 2015). Ten ${ }^{14} \mathrm{C}$ samples are from palisade contexts and nine are from contexts associated with residential structures and a large, two-tiered platform mound (Mound 14). These samples are informative for the creation of Bayesian models focused on understanding the foundation of the settlement, timing of palisade construction, and iterative modifications.

Wood charcoal (Salicaceae) from a circular bastion trench in the northwest corner of the village was sampled for ${ }^{14} \mathrm{C}$ dating (UCIAMS-164697). This charcoal is interpreted as providing a terminus post quem (TPQ) for the context because it may be residual material from a context predating the palisade. This palisade section is superimposed by a bastion rebuild trench (Figure 2a) and wood charcoal (Salicaceae) from a probable posthole in this circular bastion trench was sampled for ${ }^{14} \mathrm{C}$ dating (UCIAMS-164695). The dated charcoal for UCIAMS-164695 is interpreted as a fragment of a removed palisade post that was burnt before insertion into the trench. These contexts are superimposed by a collapse layer (Figure 2a) and wood charcoal (Quercus) from this layer was sampled for ${ }^{14} \mathrm{C}$ dating (UCIAMS-164699). The dated charcoal for UCIAMS-164699 is interpreted as burnt palisade construction material that provides a date for the circular bastion.

A disarticulated duck synsacrum (Anatidae) sample from an amorphous deposit cut by a different circular bastion along the palisade's north wall (Figure 2b) was sampled for ${ }^{14} \mathrm{C}$ dating (UCIAMS-164709). No other suitable samples for ${ }^{14} \mathrm{C}$ dating were found in this amorphous deposit. This deposit is interpreted as part of a structure pre-dating this palisade section. The $\delta^{13} \mathrm{C}$ value $(-20.9 \%)$ for this sample suggests a predominantly terrestrial diet for this duck and the ${ }^{14} \mathrm{C}$ measurement from this sample was calibrated using the terrestrial calibration curve only (Richards and Hedges 1999). The dated disarticulated bone sample is interpreted as a $T P Q$ for the context because it may be residual and may date a time 
before the creation of the deposit. A porous wood (species unidentified) charcoal sample from a posthole within this circular bastion along the north palisade wall was also sampled for ${ }^{14} \mathrm{C}$ dating (UCIAMS-164700) and is interpreted as a fragment of a removed burned palisade post.

A disarticulated duck tibia (Anatidae) sample from this circular bastion trench along palisade's north wall was further sampled for ${ }^{14} \mathrm{C}$ dating (UCIAMS-164708). No other suitable samples for ${ }^{14} \mathrm{C}$ dating were found in this bastion trench context. The disarticulated duck bone sample is interpreted as providing a $T P Q$ for the context because it may be residual and may date a time before the creation of the wall trench. The $\delta^{13} \mathrm{C}$ value $(-15.5 \%$ ) derived from AMS for this sample suggests a marine component in the diet, which is not surprising because migratory patterns of ducks often include warm coastal areas (Chisholm et al. 1982; Schoeninger et al. 1983). A $\delta^{13} \mathrm{C}$ value derived from a subsample of the pretreated bone would further allow for the estimation of the percentage of diet from terrestrial/marine resources, but this is not available. Therefore, this sample has not been subjected to ${ }^{14} \mathrm{C}$ calibration or Bayesian chronological modeling.

A circular bastion along the north palisade wall is superimposed by a rectangular bastion (Figure $2 b$ ). Wood (willow/poplar) charcoal from the base of the west flank of this rectangular bastion was sampled for ${ }^{14} \mathrm{C}$ dating (UCIAMS-145763). This dated charcoal is interpreted as a fragment from the base of a removed burned bastion post. Two hickory nutshell (Carya) samples from post-molds in the west flank of the same rectangular bastion were sampled for ${ }^{14} \mathrm{C}$ dating (UCIAMS-145761, UCIAMS-145762) and are interpreted as a $T P Q$ for the context because durable nutshell samples often have high-potential to be redeposited as residual material. A cucurbit rind (Cucurbitaceae) from a burned context near this rectangular bastion was also sampled for dating (UCIAMS-164694) and is interpreted as providing a date that approximates the time this area burned. This burned area is adjacent to, and of same orientation as the palisade wall; therefore, the sample is interpreted as providing a date for a time when the palisade was present. Further, the sampled burned context superimposes the circular bastion in this area (Figure $2 b$ ), suggesting that UCIAMS-164694 provides a date for the rectangular bastion.

Porous wood (species unidentified) charcoal from the floor of a wall-trench structure north of the fortified village was sampled for ${ }^{14} \mathrm{C}$ dating (UCIAMS-169486). This context contained a mix of grit- and shell-tempered pottery sherds likely related to the domestic use of this structure. Thatched monocot stems from the floor of a second structure with Lohmann Phase (AD 1050-1100) pottery in this area were also sampled for

${ }^{14} \mathrm{C}$ dating (UCIAMS-164698). These two samples are interpreted as domestic materials left behind in their respective structures and as providing dates for the earliest Mississippi-era village occupation; although, it is also feasible that either or both may be residual and could serve as a TPQ for these contexts. $\mathrm{A}^{14} \mathrm{C}$ measurement from a nearby sample of unidentified wood charcoal acquired from a solid-earth core of a paleochannel adjacent to these structures (UCIAMS-164692) was excluded from Bayesian modeling because it is unclear how this sample relates to the village occupation.

We used solid-earth coring methods to obtain an unidentified wood charcoal sample for ${ }^{14} \mathrm{C}$ dating (UCIAMS-164693) from a structure on or below the upper platform of Mound 14. Similarly, we recovered a monocot stem (UCIAMS-164696) from a core of a structure below Mound 
14's lower platform. Both samples are modeled as $T P Q$ because precise contextual data are not available from the solid-earth core data. Further, both samples may be residual and may date a time before the creation of their respected contexts.

Thatched unidentified plant material residing atop the roof and wall elements of a burned structure in the northeastern corner of the village was sampled for ${ }^{14} \mathrm{C}$ dating (Beta-281698). The sample is interpreted as construction material and provides a date for the construction or modification of the structure. The elevated $\delta^{13} \mathrm{C}$ value $\left(-10.4 \%\right.$ ) of this sample strongly suggests that the dated material is a $\mathrm{C}_{4}$ plant (Cerling et al. 1998: Figure 4), possibly a maize plant incorporated into the thatching (Bender 1968, 1971; Lowdon 1969). Alternatively, if the sample is from discarded food remnants, then it likely provides a date for the use of the structure. Thatched monocot stems from immediately above the floor of a second burnt structure in the same area were sampled for ${ }^{14} \mathrm{C}$ dating (UCIAMS-145759). A series of burnt timbers were found immediately above the burnt thatch, within an infilling episode, and the outer ring (species unidentified) of one of these burnt timbers was sampled for ${ }^{14} \mathrm{C}$ dating (UCIAMS-145760). Both samples (UCIAMS-145759, UCIAMS-145760) are interpreted as construction materials that provide dates for the construction and/or modification of this structure, which was rebuilt and expanded on a minimum of three occasions. This interpretation of the ${ }^{14} \mathrm{C}$ samples is strengthened because it is likely that these two samples are the same age, as the measurements pass a chi-square test $(\mathrm{T}=0.8$; $\mathrm{df}=1$; T'(0.05)=3.8) (Ward and Wilson 1978). A persimmon seed (Diospyros) from a pit located in the southeast corner of a nearby non-burnt structure was sampled for ${ }^{14} \mathrm{C}$ dating (UCIAMS-153692). This seed is interpreted as material stored within the pit and should provide a date for the pit's use. Although, it is also feasible that the seed may be residual and could serve as a TPQ for this context.

The ${ }^{14} \mathrm{C}$ dates were modeled with the prior assumption that they are representative of a single, relatively uniform phase of activity. Boundaries were placed around this sequence in OxCal to estimate a start and end date. Sequences were created in this phase to reflect the stratigraphic ordering of the ${ }^{14} \mathrm{C}$ samples (Figures 2-3). A Charcoal Outlier Model (Bronk Ramsey 2009b) was adopted as a strategy for accounting for the unknown in-built age offset in wood charcoal samples to create a more accurate and robust model (Hamilton and Kenney 2015). The model assumes an exponential distribution, with an exponential constant $\tau$ of 1 taken over the range -10 to 0 , of the charcoal dates (Bronk Ramsey $2009 \mathrm{~b}$ ). The shifts are then scaled by a common scaling factor that can lie anywhere between $10^{0}$ and $10^{3}$ years. Non-charcoal ${ }^{14} \mathrm{C}$ measurements were given a prior probability of $5 \%$ of being statistical outliers, using the General Outlier Model.

It should be noted that the Charcoal Outlier Model algorithm iteratively downweighs the impact of wayward results until the model runs freely and consistently, irrespective of the overlap integral between the posterior results and standardized likelihoods (i.e.: the agreement) (Bronk Ramsey 2009b; Dee and Bronk Ramsey 2014). Following best practice (Bayliss 2015), the Amodel agreement value is still reported to evaluate the agreement between the model parameters and the ${ }^{14} \mathrm{C}$ dates; however, there is no clear position about what the final agreement means when running the Charcoal Outlier Model, which makes the models with this outlier algorithm difficult to evaluate. Despite these issues, the Charcoal Outlier Model is still used because seven of the $19{ }^{14} \mathrm{C}$ measurements are potentially old wood charcoal, hence, modeling these as Charcoal 
Outliers effectively deals with potential old wood effects. Additionally, the results of the primary model do not meaningfully change when the Charcoal Outlier Model is not employed and produce an $A_{\text {model }}$ value with good overall agreement $\left(\mathrm{A}_{\text {model }}=91.6\right)$.

The algorithm used for the primary model with the Charcoal Outlier Model algorithm can be directly derived from the model structure shown in Figure 3. The primary model shows good overall agreement $\left(\mathrm{A}_{\text {model }}=88.5\right)$ between the ${ }^{14} \mathrm{C}$ dates and the model assumptions. The model estimates that the earliest activity on the site began in cal AD 990-1165 (95\% probability; Figure 3; Primary Model: Start Lawrenz), and probably in cal AD 1075-1150 (68\% probability), when initial Mississippi settlements were founded further upstream (Wilson et al. 2018). The model estimates that palisade construction with circular bastions began in cal AD 1150-1230 (95\% probability; Figure 3; Primary Model: Start Circular Bastion Palisade), and probably in cal AD 1165-1205 (68\% probability). Palisade modifications and repair are estimated to have continued for the next 15-125 yr (95\% probability; Figure 6; Primary Model: Palisade Span), and probably for 40-85 yr (68\% probability). The model estimates construction of the palisade with rectangular bastions began in cal AD 1200-1260 (95\% probability; Figure 3; Primary Model: Start Rectangular Bastion Palisade), and probably in cal AD 1210-1250 (68\% probability). Palisade modifications and repair are estimated to have ended in cal AD 1215-1305 (95\% probability; Figure 3; Primary Model: End Rectangular Bastion Palisade), and probably in cal AD 1230-1265 (68\% probability). Activity on the site is estimated to have ended in cal AD 1295-1450 (95\% probability; Figure 3; Primary Model: End Lawrenz), probably in cal AD 1300-1405 (68\% probability), spanning 150-420 yr (95\% probability; Figure 6; Primary Model: Lawrenz Span), probably for $175-310$ yr (68\% probability). 


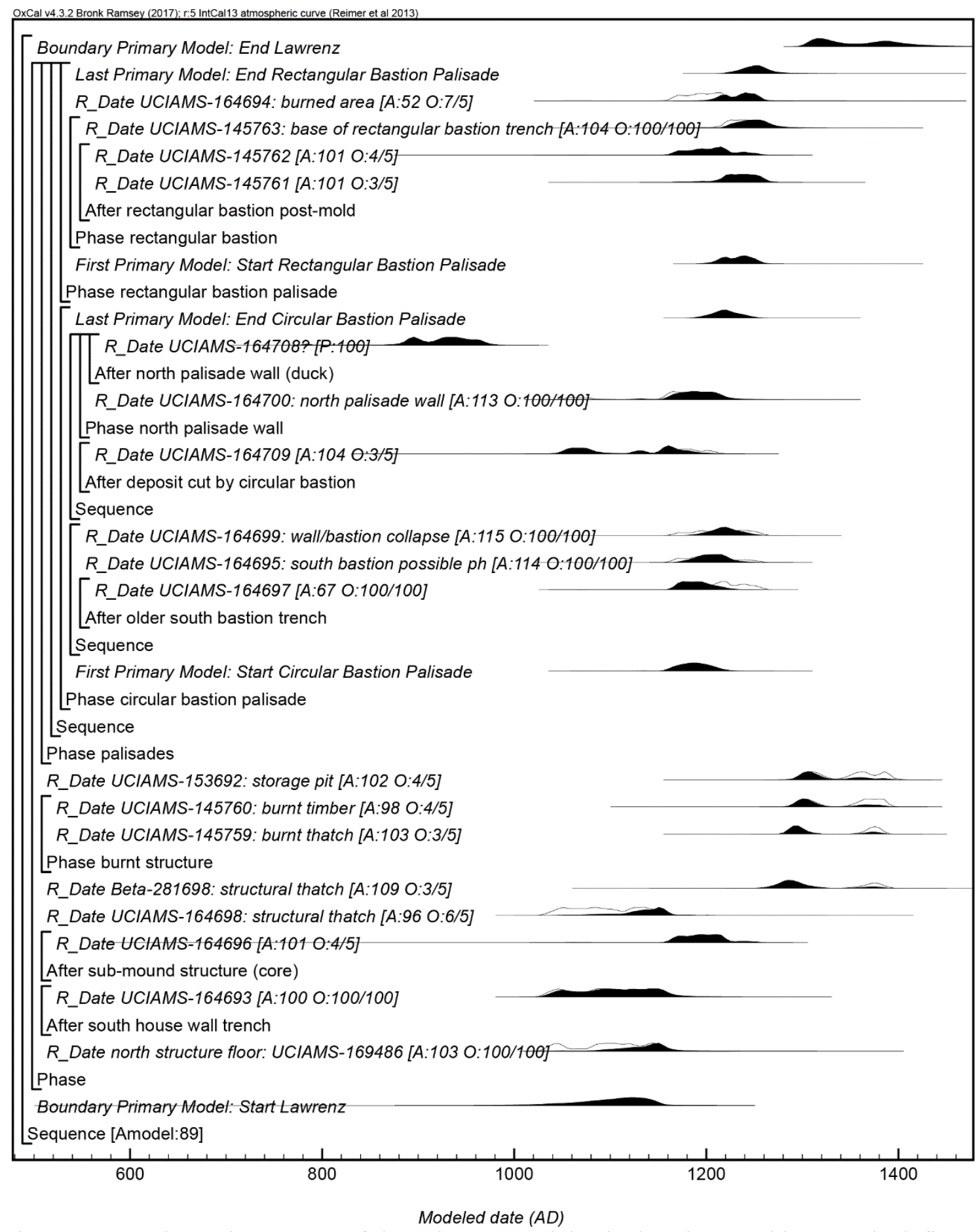

Figure 3: Results and structure of the primary model. The brackets and keywords define the model structure. The outlined distribution is the result of ${ }^{14} \mathrm{C}$ calibration and the solid distributions are the chronological model results. The large square 'brackets' along with the OxCal keywords define the overall model exactly. 


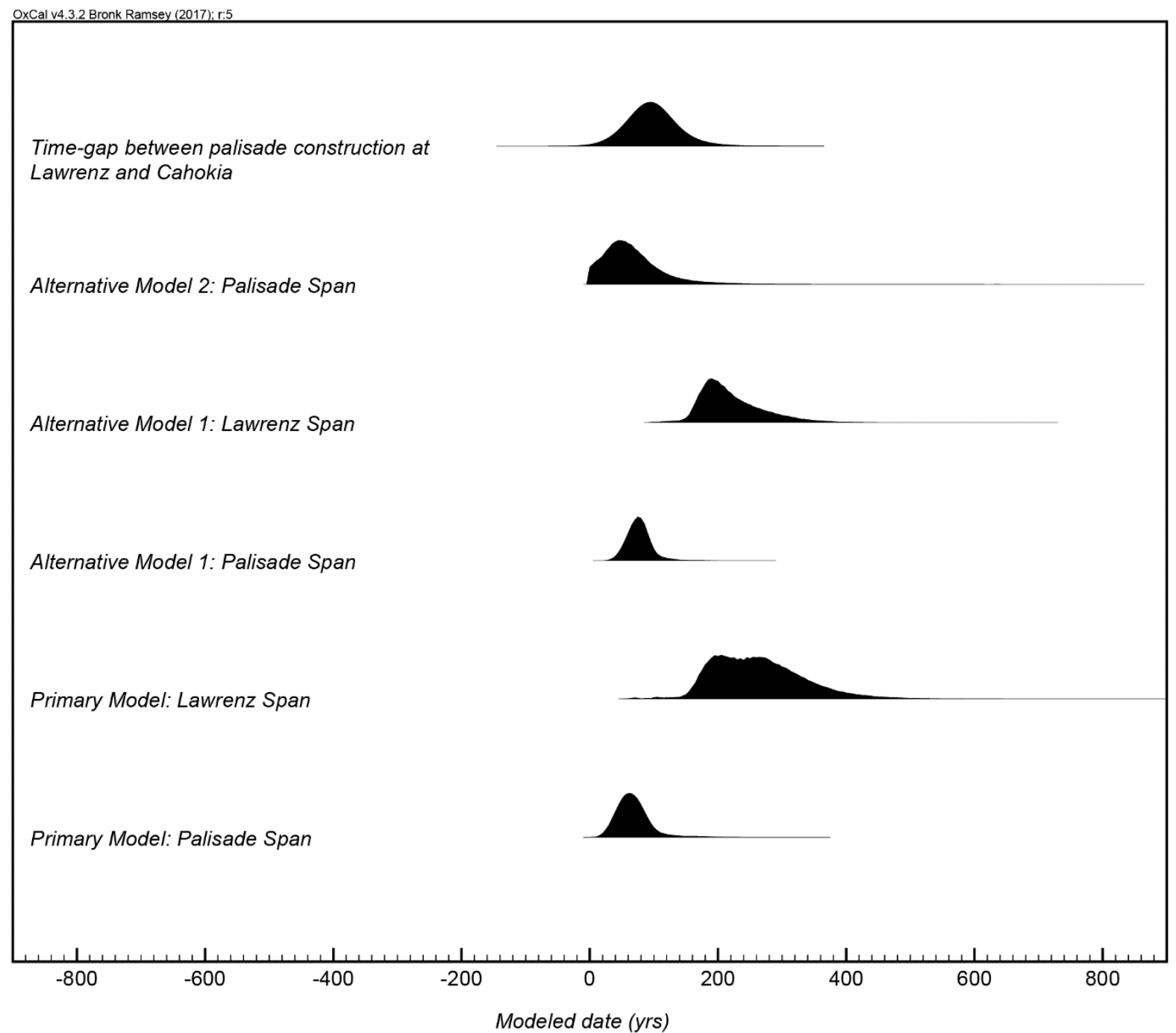

Figure 6: Posterior probabilities for estimated spans in the Bayesian models. The time-gap between palisade construction at Lawrenz and Cahokia was calculated by subtracting the posterior probability for palisade construction at Cahokia presented in the primary model of Krus (2016) from the posterior probability for palisade construction at Lawrenz presented in this study. 


\section{DISCUSSION}

The Lawrenz settlement chronology is of intrinsic interest for understanding the preColumbian history of the CIRV, as it is the largest and longest inhabited Mississippian village in this area and the only CIRV settlement with a robust trench-built palisade and evolving forms of bastions. The Bayesian models for the settlement chronology produced very similar results and suggest that the occupation spanned much of the Mississippi Period. The primary model is preferred for interpretation because it offers a more conservative treatment of the ${ }^{14} \mathrm{C}$ data than the alternative models. While the primary model is preferred, the results of the alternative models are parsimonious, especially at $68 \%$ probability (Figures 3-6; Tables 2-3). At $68 \%$ probability, the primary model estimates that the dated activity at Lawrenz began in either the late $11^{\text {th }}$ century or early-mid $12^{\text {th }}$ century AD and that the first palisade with circular bastions was constructed in the late $12^{\text {th }}$ century. Activity at the site is estimated to have ended in the $14^{\text {th }}$ century at $68 \%$ probability.

Importantly, the palisade was maintained with repairs and rebuilds until the mid-late $13^{\text {th }}$ century, including a major rebuild with rectangular bastions in the early $13^{\text {th }}$ century. The estimated use life of the palisade (40-85 yr; 68\% probability; Figure 6; Primary Model: Palisade Span) suggests that the structure was standing for at least several decades and, potentially, a century. These results are similar to other Bayesian estimates for the use lives of Mississippian bastioned palisades (Krus 2016; Krus and Cobb 2018), but contrast with previous shorter-use life estimates based on wood decay rates (Bigman et al. 2011; Iseminger et al. 1990; Scarry 1998). The longer use-life of the Lawrenz palisades suggest that the true use-life of a palisade may only be partially contingent on the durability of its construction materials. The magnetometry and excavation results at Lawrenz indicate that the palisade had numerous repair trenches and substantial rebuilds (Wilson and Pike 2015), suggesting that maintaining Lawrenz's bastioned palisade was a multigenerational effort and that inhabitants repaired and rebuilt the palisade walls when and where needed.

The longevity of palisades at Lawrenz are important because bastioned palisades have long been interpreted as evidence for the militarization of Mississippian settlements. At Lawrenz, bastions are regularly spaced at 21-44 m, which correlates globally with the use of the bow and arrow as projectile weapons (Keeley et al. 2007:70-72; Milner 2000:58), and are large enough to hold defenders who could concentrate fire onto closely approaching attackers (Keeley et al. 2007; Milner 1999; 2000; 2007). Bastions likely increased the line of sight for defending archers, while shielding their visibility (Keeley 1996:56). The presence of bastioned palisades provides evidence for coordinated defending and attacking Mississippian forces. Regardless of whether real or perceived, the anticipation of attack must have served as a strong incentive for the inhabitants of Lawrenz to maintain their palisades. 


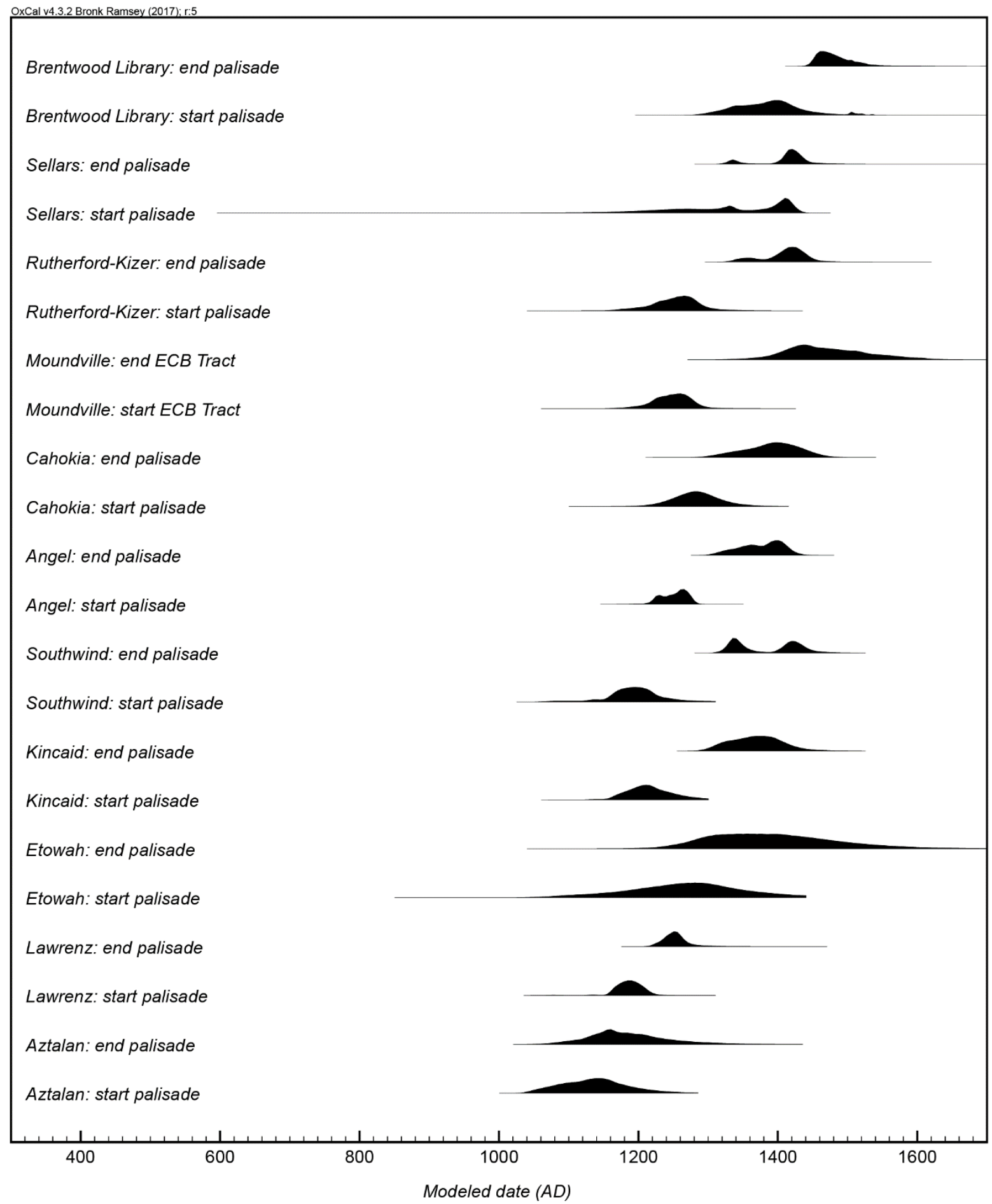

Figure 7: Posterior probability densities for the construction and use of Mississippian bastioned palisades subjected to scientific dating and Bayesian chronological modeling. Posterior probabilities for Lawrenz derive from the primary model presented in this study and the other posterior probabilities derive from the primary Bayesian models presented in Krus (2016) and Krus and Cobb (2018).

Orendorf, another major Mississippian center in the CIRV, was also fortified with a singlepost palisade containing bastions. Loose interpretations for Orendorf's fortification chronology, which are based on associated diagnostic ceramics, suggest that it was present 
from AD 1200-1250 (Harn 1994:24; Santure 1981; Wilson 2012; 2015), so may have been contemporaneous with the fortification at Lawrenz.

The only Mississippian bastioned palisade clearly constructed earlier than Lawrenz was at Aztalan (located $350 \mathrm{~km}$ north in southern Wisconsin). Bayesian estimates for palisade construction at Aztalan are cal AD 1080-1180 at (68\% probability; Figure 7; Aztalan: start palisade; Krus 2016). In contrast, estimates for construction of Cahokia's palisade are cal AD 1245-1315 (68\% probability; Figure 7, Cahokia: start palisade; Krus 2016), which is 55135 yr (68\% probability) after Lawrenz (Figure 6; Time-gap between palisade construction at Lawrenz and Cahokia), suggesting a more militarized way of Mississippian life existed at Lawrenz and other northern Mississippian territories and outposts before Cahokia. Krus (2016) shows that the remainder of the ${ }^{14} \mathrm{C}$ dated bastioned palisades in the midcontinental U.S. were first constructed in the AD 1200s (Figure 7). This coincides with the end of the Medieval Climate Anomaly, which brought decreased summer precipitation (i.e., droughty conditions) that is believed to have caused declines in crop production, increased food scarcity, socio-political instability, and a need for enhanced security (Bird et al. 2017; Milner 2007; Milner et al. 2013). In this socio-environmental context, the Bold Counselor Oneota spread across the upper midcontinental U.S. and into the CIRV around AD 1300 (Esarey and Conrad 1998; Lieto and O'Gorman 2014; Santure et al. 1990; Steadman 1998), although only limited artefactual evidence at Lawrenz (i.e., surface-collected Bold Counselor jar, pipestone pieces, and small galena fragments) supports direct interaction with Oneota groups. Robust ${ }^{14} \mathrm{C}$ dating and chronological modeling of villages with distinct Oneota components will help clarify these relationships.

\section{CONCLUSION}

Cultural diversity reflected by an array of architectural styles, mound use, placement, structure, and ceramic typologies associated with village communities (Green 1993; Wilson 2010) have complicated our ability to tease apart sociopolitical affiliations through time at Late Woodland and Mississippian sites in the CIRV. In the case of Lawrenz, diagnostic pottery and calibrated dates (Table 1) from samples of disarticulated animal bone, short-lived plants, nutshell, thatch, and wood charcoal suggested that activity took place primarily in the Mississippi Period (Wilson and Pike 2015). The long occupational span at Lawrenz starkly contrasts with the notion that communities (e.g., Orendorf) located to the north in the CIRV were shorter-lived, representing a generation or two. While the unmodeled ${ }^{14} \mathrm{C}$ data proved to be informative for a range-finder assessment of the site chronology, when taken alone the calibrated dates do not provide good evidence to precisely assess the settlement history. Further, interpreting the ${ }^{14} \mathrm{C}$ calibrations proved to be complicated due to a marine component in the diet of one of the ${ }^{14} \mathrm{C}$ measurements from a duck bone.

Bayesian chronological models of these data provide high-resolution probabilistic estimates for the occupation chronology and the analysis presented in this paper provides another example of the type of social histories that can be inferred from modeling Mississippi Period activity. In the case of Lawrenz, the Bayesian modeling suggests that the village was established in the late $11^{\text {th }}$ century or early-mid $12^{\text {th }}$ century AD and that continuous occupation of the village lasted for two-three centuries.

Previous studies have suggested that the periodicity of warfare was at chronic levels in many Mississippian areas from AD 1200-1400 (Cobb and Giles 2009; Dye 2008; Emerson 2007; Krus 2016; Milner 1999, 2000, 2007; Milner et al. 2013; Wilson 2012). In contrast, the 
palisade at Lawrenz was likely constructed before AD 1200 (Figure 7). Bayesian estimates for palisade chronologies for sites north of Cahokia (Lawrenz and Aztalan, Figure 7) suggest potential episodes of militarization earlier than AD 1200, specifically sometime in the late AD 1000s to mid-AD 1150s. Future fine-grain analyses and comparisons are still needed to understand the historical nuances of how these past conflicts unfolded and the different pulses and levels of inter-group violence that played out in different parts of the late preColumbian midcontinental U.S.

To better understand the dynamic social history of the CIRV at a higher precision and accuracy, Lawrenz and other archaeological settlements in the area require a more robust AMS ${ }^{14} \mathrm{C}$ dataset using single-entities of articulated bone or short-lived material that are strongly related to the function of the context from which they were recovered. At Lawrenz, all excavated organic samples that contain secure taphonomic links to their corresponding context have been dated. Consequently, the chronology presented here is can only be improved by future excavations that retrieve taphonomically suitable ${ }^{14} \mathrm{C}$ samples.

\section{ACKNOWLEDGEMENTS}

We would like to thank the Hardwick and Robertson families for granting us permission to conduct research on their properties and serving as excellent stewards of the site. Our gratitude must also be extended to our 2010-2016 field crews, Erica Ausel, John Flood, Nicole Geske, Kathryn Parker, Derek Hamilton, and Mark Schurr. The Glenn A. Black Laboratory of Archaeology at Indiana University provided the Bartington Grad 601-2 dual gradiometer and GeoProbe coring rig. Portions of this research have been funded by the National Science Foundation (SMA 1262530) and IUPUI's Center for Research and Learning.

\section{REFERENCES}

Ashmore PJ. 1999. Radiocarbon dating: avoiding errors by avoiding mixed samples. Antiquity 73:124-30.

Bayliss A. 2009. Rolling out revolution: using radiocarbon dating in archaeology. Radiocarbon 51(1):123-47.

Bayliss A. 2015. Quality in Bayesian chronological models in archaeology. World Archaeology 47(4):677-700.

Bayliss A, Bronk Ramsey C, van der Plicht J, Whittle A. 2007. Bradshaw and Bayes: Towards a Timetable for the Neolithic. Cambridge Archaeological Journal 17(1):1-28.

Bayliss A, van der Plicht J, Bronk Ramsey C, McCormac G, Healy F, Whittle A. 2011. Towards generational time-scales: The quantitative Interpretation of Archaeological Chronologies. In: Whittle A, Healy F, Bayliss A, editors. Gathering Time: Dating the Early Neolithic Enclosures of Southern Britain and Ireland. Oxford: Oxbow Books. p 17-59.

Bender MM. 1968. Mass spectrometric studies of carbon 13 variations in corn and other grasses. Radiocarbon 10(2):468-72.

Bender MM. 1971. Variations in the $13 \mathrm{C} / 12 \mathrm{C}$ ratios of plants in relation to the pathway of photosynthetic carbon dioxide fixation. Phytochemistry 10(6):1239-44.

Bigman DP, King A, Walker CP. 2011. Recent geophysical investigations and new interpretations of Etowah's palisade. Southeastern Archaeology 30(1):38-50.

Bird BW, Wilson JJ, Gilhooly III WP, Steinman BA, Stamps L. 2017. Midcontinental Native American population dynamics and late Holocene hydroclimate extremes. Scientific Reports 7:41628. 
Bronk Ramsey C. 1995. Radiocarbon calibration and analysis of stratigraphy: The OxCal program. Radiocarbon 37(2):425-30.

Bronk Ramsey C. 1998. Probability and Dating. Radiocarbon 40(1):461-74.

Bronk Ramsey C. 2001. Development of the radiocarbon calibration program. Radiocarbon 43(2A):355-63.

Bronk Ramsey C. 2009a. Bayesian analysis of radiocarbon dates. Radiocarbon 51(1):337-60.

Bronk Ramsey C. 2009b. Dealing with outliers and offsets in radiocarbon dating. Radiocarbon 51(3):1023-45.

Buck CE, Cavanagh WG, Litton CD. 1996. Bayesian approach to interpreting archaeological data. Chichester: John Wiley \& Sons, Ltd.

Buck CE, Kenworthy JB, Litton CD, Smith AFM. 1991. Combining archaeological and radiocarbon information: a Bayesian approach to calibration. Antiquity 65(249):808-21.

Cerling TE, Ehleringer JR, Harris JM. 1998. Carbon dioxide starvation, the development of C4 ecosystems, and mammalian evolution. Philosophical Transactions of the Royal Society B: Biological Sciences 353(1365):159-71.

Chisholm BS, Nelson DE, Schwarcz HP. 1982. Stable carbon isotope ratios as a measure of marine versus terrestrial protein in ancient diets. Science 216:1131-2.

Cobb CR, Giles B. 2009. War is shell: the ideology and embodiment of Mississippian conflict. In: Nielsen A, Walker W, editors. Warfare in Cultural Context: Practice, Agency, and the Archaeology of Violence. Tucson, Arizona: University of Arizona Press. p 84-108.

Conner MD. 2016. Mississippian Habitation Components at Dickson Mounds in the Central Illinois River Valley. Midcontinental Journal of Archaeology 41(1):67-92.

Conrad LA. 1991. The Middle Mississippian Cultures of the Central Illinois Valley. In: Emerson TE, Lewis RB, editors. Cahokia and the Hinterlands: Middle Mississippian Cultures of the Midwest. Urbana, Illinois: University of Illinois Press. p 119-63.

Conrad LA, Harn AD. 1972. The Spoon River Culture in the Central Illinois Valley. Unpublished manuscript on file at Western Illinois University Archaeological Research Lab and Dickson Mounds Museum.

Dee M, Bronk Ramsey C. 2014. High-Precision Bayesian Modeling of Samples Susceptible to Inbuilt Age. Radiocarbon 56(1):83-94.

Dye DH. 2008. War Paths, Peace Paths: An Archaeology of Cooperation and Conflict in Native Eastern North America. New York: AltaMira Press.

Emerson TE. 2007. Evidence for Late Pre-Columbian Warfare in the North American Midcontinent. In: Chacon RJ, Mendoza RG, editors. North American Indigenous Warfare and Ritual. Tucson: University of Arizona Press. p 129-48.

Esarey D. 2000. The Late Woodland Maples Mills and Mossville Phase Sequence in the Central Illinois River Valley. In: Emerson TE, McElrath DL, Fortier AC, editors. Late

Woodland Societies: Tradition and Transformation across the Midcontinent. Lincoln: University of Nebraska. p 387-410.

Esarey D, Conrad LA. 1998. The Bold Counselor Phase of the Central Illinois River Valley: Oneota's Middle Mississippian Margin. Wisconsin Archaeologist 79(2):38-61.

Green W. 1993. A Prehistoric Frontier in the Prairie Peninsula: Late Woodland Upland

Settlement and Subsistence Patterns. Illinois Archaeology 5(1 and 2):201-14.

Green W, Nolan DJ. 2000. Late Woodland Peoples in West-Central Illinois. In: Emerson TE, McElrath DL, Fortier AC, editors. Late Woodland Societies: Tradition and Transformation across the Midcontinent. Lincoln: University of Nebraska. p 345-86.

Hamilton WD, Kenney J. 2015. Multiple Bayesian modelling approaches to a suite of radiocarbon dates from ovens excavated at Ysgol yr Hendre, Caernarfon, North Wales. Quaternary Geochronology 25:75-82 
Hamilton WD, Krus AM. 2018. The myths and realities of Bayesian chronological modeling revealed. American Antiquity 82:in press.

Harn AD. 1975. Cahokia and the Mississippian Emergence in the Spoon River Area of Illinois. Transactions of the Illinois State Academy of Sciences 68(4):414-34.

Harn AD. 1994. Variation in Mississippian Settlement Patterns: The Larson Settlement System in the Central Illinois River Valley. Springfield: Illinois State Museum.

Hart JP, Asch DL, Scarry CM, Crawford GW. 2002. The age of the common bean (Phaseolus vulgaris L.) in the northern Eastern Woodlands of North America. Antiquity 76:377-85.

Holt JZ. 2005. Animal Remains from the Carter Creek Site: Late Woodland Adaptive Strategies in the Frontier of West Central Illinois. Midcontinental Journal of Archaeology 30(1):37-65.

Holt JZ, Feathers JK. 2003. Dating the Middle to Late Woodland transition in the Illinois Valley: Radiocarbon and thermoluminescence dates from the Baehr-Gust site. Midcontinental Journal of Archaeology 28(1):73-93.

Iseminger WR, Pauketat TR, Koldehoff B, Kelly LS, Blake L. 1990. East palisade investigations. The Archaeology of the Cahokia Palisade. Springfield, Illinois: Illinois Historic Preservation Agency.

Keeley LH. 1996. Warfare Before Civilization. Oxford: Oxford University Press.

Keeley LH, Fontana M, Quick R. 2007. Baffles and Bastions: The Universal Features of Fortifications. Journal of Archaeological Research 15(1):55-95.

Krus AM. 2016. The Timing of Precolumbian Militarization in the U.S. Midwest and Southeast. American Antiquity 81(2):375-88.

Krus AM, Cobb CR. 2018. The Mississippian fin de siècle in the middle Cumberland region of Tennessee. American Antiquity 82:in press.

Krus AM, Cook R, Hamilton D. 2015. Bayesian Chronological Modeling of SunWatch, a Fort Ancient Village in Dayton, Ohio. Radiocarbon 57(5):965-77.

Lieto JR, O'Gorman JA. 2014. A Preliminary Analysis of Oneota and Mississippian Serving Vessels at the Morton Village Site, West-Central Illinois. North American Archaeologist 35(3):24355.

Lowdon JA. 1969. Isotopic fractionation in corn. Radiocarbon 11(2):391-3.

Milner GR. 1999. Warfare in Prehistoric and Early Historic Eastern North America. Journal of Archaeological Research 7(2):105-51.

Milner GR. 2000. Palisaded Settlements in Prehistoric Eastern North America. In: Tracy JD, editor. City Walls. Cambridge, United Kingdom: Cambridge University Press. p 4670.

Milner GR. 2007. Warfare, population, and food production in prehistoric Eastern North America. In: Chacon RJ, Mendoza RG, editors. North American Indigenous Warfare and Ritual. Tucson: University of Arizona Press. p 182-201.

Milner GR, Chaplin G, Zavodny E. 2013. Conflict and Societal Change in Late Prehistoric Eastern North America. Evolutionary Anthropology: Issues, News, and Reviews 22(3):96-102.

Reimer PJ, Bard E, Bayliss A, Beck JW, Blackwell PG, Bronk Ramsey C, Grootes PM, Guilderson TP, Haflidason H, Hajdas I, Hatte C, Heaton TJ, Hoffmann DL, Hogg AG, Hughen KA, Kaiser KF, Kromer B, Manning SW, Niu M, Reimer RW, Richards DA, Scott EM, Southon JR, Staff RA, Turney CSM, van der Plicht J. 2013. IntCal13 and Marine13 Radiocarbon Age Calibration Curves 0-50,000 Years cal BP. Radiocarbon 55(4):1869-87.

Santure SK. 1981. The Changing Community Plan of Settlement C. In: Esarey D, Conrad LA, editors. The Orendorf Site: Preliminary Working Papers 1981. Macomb, Illinois: Archaeological Research Laboratory, Western Illinois University. p 5-80.

Santure SK, Harn AD, Esarey D. 1990. Archaeological Investigations at the Morton Village 
and Norris Farms 36 Cemetery. Springfield: Illinois State Museum.

Scarry CM. 1998. Domestic Life on the Northwest Riverbank at Moundville. In: Knight VJ, Steponaitis VP, editors. Archaeology of the Moundville chiefdom. Washington, D.C.: Smithsonian Institution Press. p 63-101.

Schoeninger MJ, Deniro MJ, Tauber H. 1983. Stable nitrogen isotope ratios of bone collagen reflect marine and terrestrial components of prehistoric diets. Science 216:1381-3.

Scott EM, Bryant C, Cook GT, Naysmith P. 2003. Is there a fifth international radiocarbon intercomparison (VIRI)? Radiocarbon 45:493-5.

Scott EM, Cook GT, Naysmith P. 2010. A report on phase 2 of the Fifth International Radiocarbon Intercomparison (VIRI). Radiocarbon 52(3):846-58.

Scott EM, Cook GT, Naysmith P, Bryant C, O'Donnell D. 2007. A report on phase 1 of the 5th international radiocarbon intercomparison (VIRI). Radiocarbon 49:409-26.

Steadman DW. 1998. The population shuffle in the central Illinois valley: A diachronic model of Mississippian biocultural interactions. World Archaeology 30(2):306-26.

Stuiver M, Kra RS. 1986. Editorial comment. Radiocarbon 28(2B):ii.

Stuiver M, Polach HA. 1977. Reporting of 14C data. Radiocarbon 19(3):355-63.

Thompson VD, Krus AM. 2018. Contemplating the history and future of radiocarbon dating in the American Southeast. Southeastern Archaeology 37:1-11.

Ward GK, Wilson SR. 1978. Procedures for Comparing and Combining Radiocarbon AgeDeterminations: A Critique. Archaeometry 20(1):19-31.

Wilson GD. 2012. Living with War: The Impact of Chronic Violence in the MississippianPeriod Central Illinois River Valley. In: Pauketat TR, editor. The Oxford Handbook of North American Archaeology. Oxford: Oxford University Press. p 523-33.

Wilson GD. 2015. Incinerated Villages in the North. In: Pauketat TR, Alt SM, editors. Medieval Mississippians: the Cahokian world. Santa Fe: School for Advanced Research. p 99-105.

Wilson GD, Melton MA, VanDerwarker AM. 2018. Reassessing the chronology of the Mississippian Central Illinois River Valley using Bayesian analysis. Southeastern Archaeology 37:22-38.

Wilson JJ. 2010. Modeling life through death in late prehistoric west-central Illinois: an assessment of paleodemographic and paleoepidemiological variability [Ph.D. Dissertation]: Binghamton University, SUNY.

Wilson JJ, Pike MD. 2015. Warfare and Community Organization at Lawrenz Gun Club: A Case Study in the Advancement of Mississippian Archaeology through Geophysics. Illinois Antiquity 50:29-31.

\section{ONLINE SUPPLEMENT}


Table 2. Posterior probabilities from the Bayesian models for the estimated start and end dates for the settlement and palisade.

\begin{tabular}{|c|c|c|c|c|c|c|}
\hline Event Dated & $\begin{array}{l}\text { Primary } \\
\text { Model } \\
\text { (95.4\% } \\
\text { probability) }\end{array}$ & $\begin{array}{l}\text { Primary } \\
\text { Model } \\
(68.2 \% \\
\text { probability) }\end{array}$ & $\begin{array}{l}\text { Alternative } \\
\text { Model } 1 \\
\text { (95.4\% } \\
\text { probability) }\end{array}$ & $\begin{array}{l}\text { Alternative } \\
\text { Model } 1 \\
\text { ( } 68.2 \% \\
\text { probability) } \\
\end{array}$ & $\begin{array}{l}\text { Alternative } \\
\text { Model } 2 \\
\text { (95.4\% } \\
\text { probability) }\end{array}$ & $\begin{array}{l}\text { Alternative } \\
\text { Model } 2 \\
\text { (68.2\% } \\
\text { probability) }\end{array}$ \\
\hline $\begin{array}{l}\text { Sengtbof } \\
\text { Eawremz } \\
\text { Eccupation } \\
\text { construction } \\
\text { ofljsade duse } \\
\text { lifich circular } \\
\text { with circular } \\
\text { bastions }\end{array}$ & 15150251230 & $4{ }_{185} 85-1205$ & 35150201210 & $5 Р Г 8 \theta^{5}-1190$ & ${ }_{1}^{1} 165-1250$ & $1 \rho_{T-90} 1220$ \\
\hline $\begin{array}{l}\text { Construction } \\
\text { of palisade } \\
\text { with } \\
\text { rectangular } \\
\text { bastions }\end{array}$ & $1200-1260$ & $1210-1250$ & $1190-1245$ & $1205-1230$ & $1205-1260$ & $1215-1245$ \\
\hline $\begin{array}{l}\text { End of } \\
\text { palisade use }\end{array}$ & $1215-1305$ & $1230-1265$ & $1220-1290$ & $1235-1265$ & $1210-1315$ & $1225-1270$ \\
\hline $\begin{array}{l}\text { End of } \\
\text { Lawrenz }\end{array}$ & $1295-1450$ & $1300-1405$ & $1295-1405$ & $1300-1340$ & $\mathrm{n} / \mathrm{a}$ & $\mathrm{n} / \mathrm{a}$ \\
\hline
\end{tabular}

Note: All dates are in cal AD.

Table 3. Posterior probabilities from the Bayesian models for the estimated spans for the settlement and palisade chronologies.

Note: All dates are in yrs.

\section{SENSITIVITY ANALYSIS}

An alternative Bayesian model was created to account for the possiblity that five of the measurements modeled as TPQ in the primary model may actually date the formation or use of their associated contexts (UCIAMS-164693, UCIAMS-164696, UCIAMS-164697, UCIAMS-145761, UCIAMS-145762). These five samples were selected for ${ }^{14} \mathrm{C}$ dating with the assumption that they securely date their context and, while this may not necessarily be the case, this possibility is explored in an alternative model as a sensitivity analysis. 
The structure of the alternative model is nearly identical to the primary model; the only difference is that five dates are modeled as being reflective of the timing of their contexts instead of being modeled as TPQ. The algorithm used for the alternative model can be directly derived from the model structure shown in Figure 4. The alternative model shows good overall agreement $\left(\mathrm{A}_{\text {model }}=91.7\right)$ between the ${ }^{14} \mathrm{C}$ dates and the model assumptions. The model estimates that the earliest activity on the site began in cal AD 1030-1160 (95\% probability; Figure 4; Alternative Model 1: Start Lawrenz), and probably in cal AD 10901150 (68\% probability). The model estimates that palisade construction began in cal AD 1150-1210 (95\% probability; Figure 4; Alternative Model 1: Start Circular Bastion Palisade), and probably in cal AD 1160-1190 (68\% probability). Palisade modifications and repair are estimated to have continued for the next 35-120 yr (95\% probability; Figure 6; Alternative Model 1: Palisade Span), and probably for 55-95 yr (68\% probability). The model estimates construction of the palisade with rectangular bastions began in cal AD 1190 1245 (95\% probability; Figure 4; Alternative Model 1: Start Rectangular Bastion Palisade), and probably in cal AD 1205-1230 (68\% probability). Palisade modifications and repair are estimated to have ended in cal AD 1220-1290 (95\% probability; Figure 4; Alternative Model 1: End Lawrenz palisade), and probably in cal AD 1235-1265 (68\% probability). Activity on the site is estimated to have ended in cal AD 1295-1405 (95\% probability; Figure 4; Alternative Model 1: End Lawrenz), probably in cal AD 1300-1340 (68\% probability), spanning 145-340 yr (95\% probability; Figure 6; Alternative Model 1: Lawrenz span), probably for $160-245 \mathrm{yr}$ (68\% probability).

A second alternative Bayesian model was created to model only the measurements related to the palisade as a sensitivity analysis to assess how the measurements from non-palisade contexts influence the posterior probabilities related to palisade construction and modification in the primary model and first alternative model. The ${ }^{14} \mathrm{C}$ dates from palisade contexts (UCIAMS-164697, UCIAMS-164695, UCIAMS-164699, UCIAMS-164700, UCIAMS145761, UCIAMS-145762, UCIAMS-145763) were modeled with the prior assumption that they are representative of a single, relatively uniform phase of activity. Boundaries were placed around this sequence in OxCal to estimate a start and end date. Sequences were created in this phase to reflect the stratigraphic ordering of the ${ }^{14} \mathrm{C}$ samples (Figure 2 and Figure 5). Measurements related to the palisade modeled as TPQ in the primary model are also modeled as $T P Q$ in this second alternative model (UCIAMS-164697, UCIAMS-145761, UCIAMS-145762). Like the primary and first alternative models, the Charcoal Outlier Model was adopted as a strategy for accounting for the unknown in-built age offset in wood charcoal samples to create a more accurate and robust model and follows the same assumptions as the Charcoal Outlier Model used in the primary model. Non-charcoal ${ }^{14} \mathrm{C}$ measurements were given a prior probability of $5 \%$ of being statistical outliers, using the General Outlier Model.

The algorithm used for the second alternative model can be directly derived from the model structure shown in Figure 5. The second alternative model shows good overall agreement $\left(\mathrm{A}_{\text {model }}=84.5\right)$ between the ${ }^{14} \mathrm{C}$ dates and the model assumptions. The model estimates that palisade construction began in cal AD 1125-1250 (95\% probability; Figure 5; Alternative Model 2: Start Palisade), and probably in cal AD 1170-1220 (68\% probability). Palisade modifications and repair are estimated to have continued for the next $1-165 \mathrm{yr}(95 \%$ probability; Figure 6; Alternative Model 2: Palisade Span), and probably for 10-90 yr (68\% probability). The model estimates construction of the palisade with rectangular bastions began in cal AD 1205-1260 (95\% probability; Figure 5; Alternative Model 2: Start Rectangular Bastion Palisade), and probably in cal AD 1215-1245 (68\% probability). 
Palisade modifications and repair are estimated to have ended in cal AD 1210-1315 (95\% probability; Figure 5; Alternative Model 2: End Palisade), and probably in cal AD 12251270 (68\% probability).

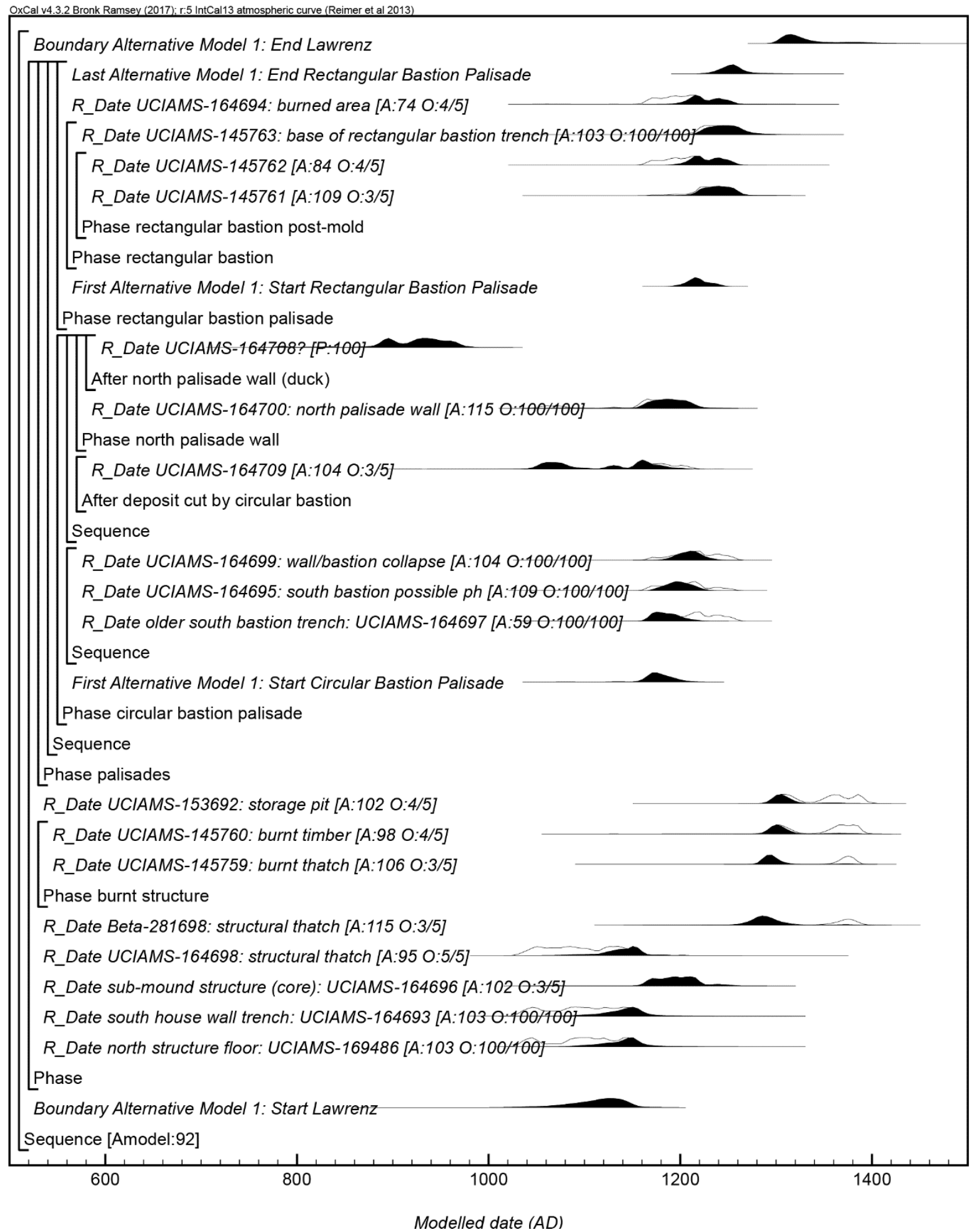

Figure 4: Results and structure of the first alternative model. The brackets and keywords define the model structure. The format is as described in Figure 3. 


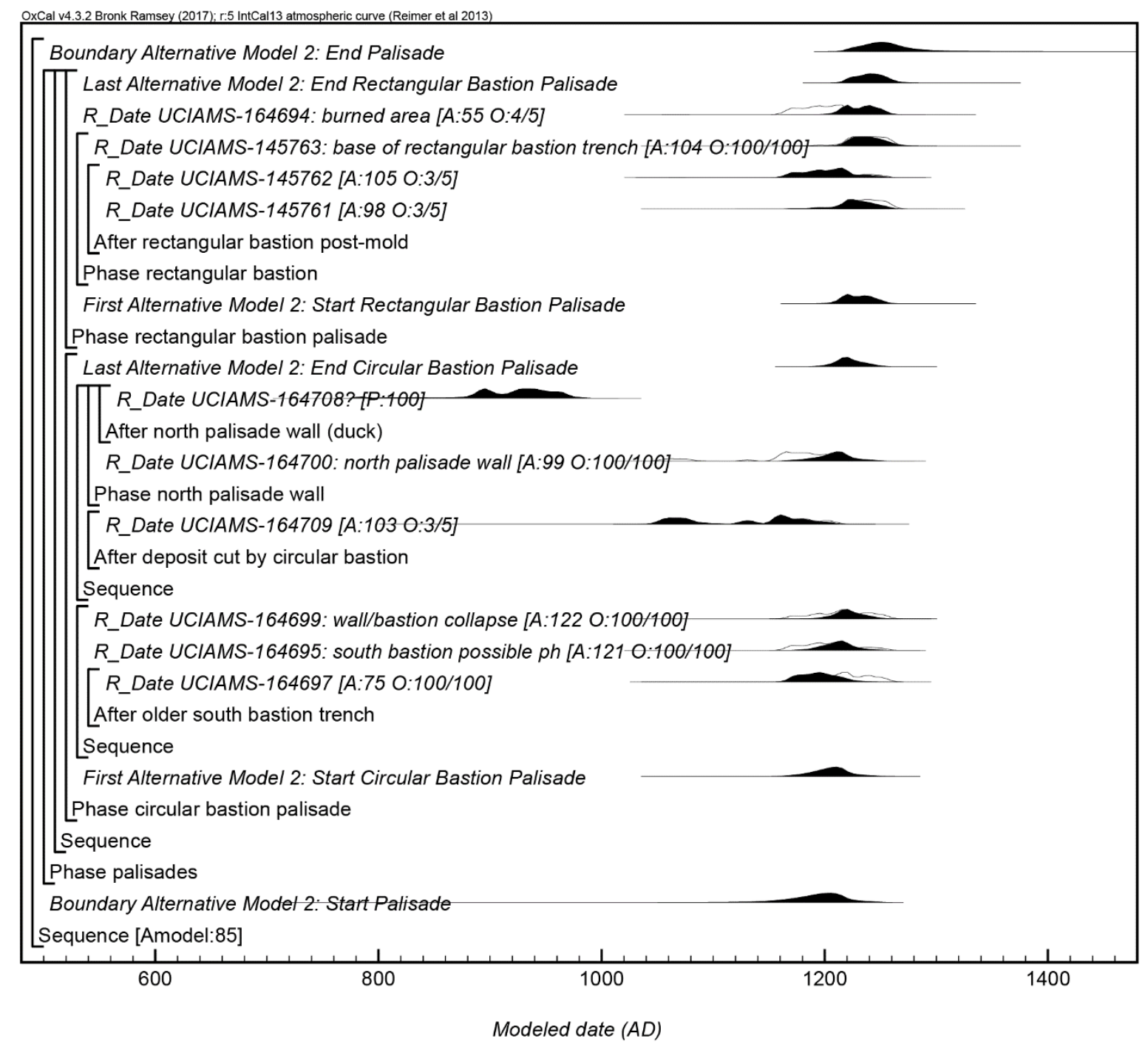

Figure 5: Results and structure of the second alternative model. The brackets and keywords define the model structure. The format is as described in Figure 3.

\section{OxCal code used for Bayesian modeling.}

Primary model:

Plot()

\{

Outlier_Model("Charcoal",Exp(1,-10,0),U(0,3),"t");

Outlier_Model("General",T(5),U(0,4),"t");

Sequence()

\{

Boundary("Primary Model: Start Lawrenz");

Phase()

\{

R_Date("north structure floor: UCIAMS-169486", 940, 15)

\{ 
Outlier("Charcoal", 1);

;

After("south house wall trench")

\{

R_Date("UCIAMS-164693", 935, 20)

\{

Outlier("Charcoal", 1);

\}

\}

After("sub-mound structure (core)")

\{

R_Date("UCIAMS-164696", 850, 20)

\{

Outlier("General", 0.05);

\}

\} ;

R_Date("UCIAMS-164698: structural thatch", 925, 20)

\{

Outlier("General", 0.05);

\}

R_Date("Beta-281698: structural thatch", 690, 40)

\{

Outlier("General", 0.05);

\};

Phase("burnt structure")

\{

R_Date("UCIAMS-145759: burnt thatch", 665, 20)

\{

Outlier("General", 0.05);

\};

R_Date("UCIAMS-145760: burnt timber", 640, 20)

\{

Outlier("General", 0.05);

;

\} ;

R_Date("UCIAMS-153692: storage pit", 625, 20)

\{

Outlier("General", 0.05);

;

Phase("palisades")

\{

Sequence()

\{

Phase("circular bastion palisade")

\{

First("Primary Model: Start Circular Bastion Palisade");

Sequence()

\{

After("older south bastion trench")

\{ 


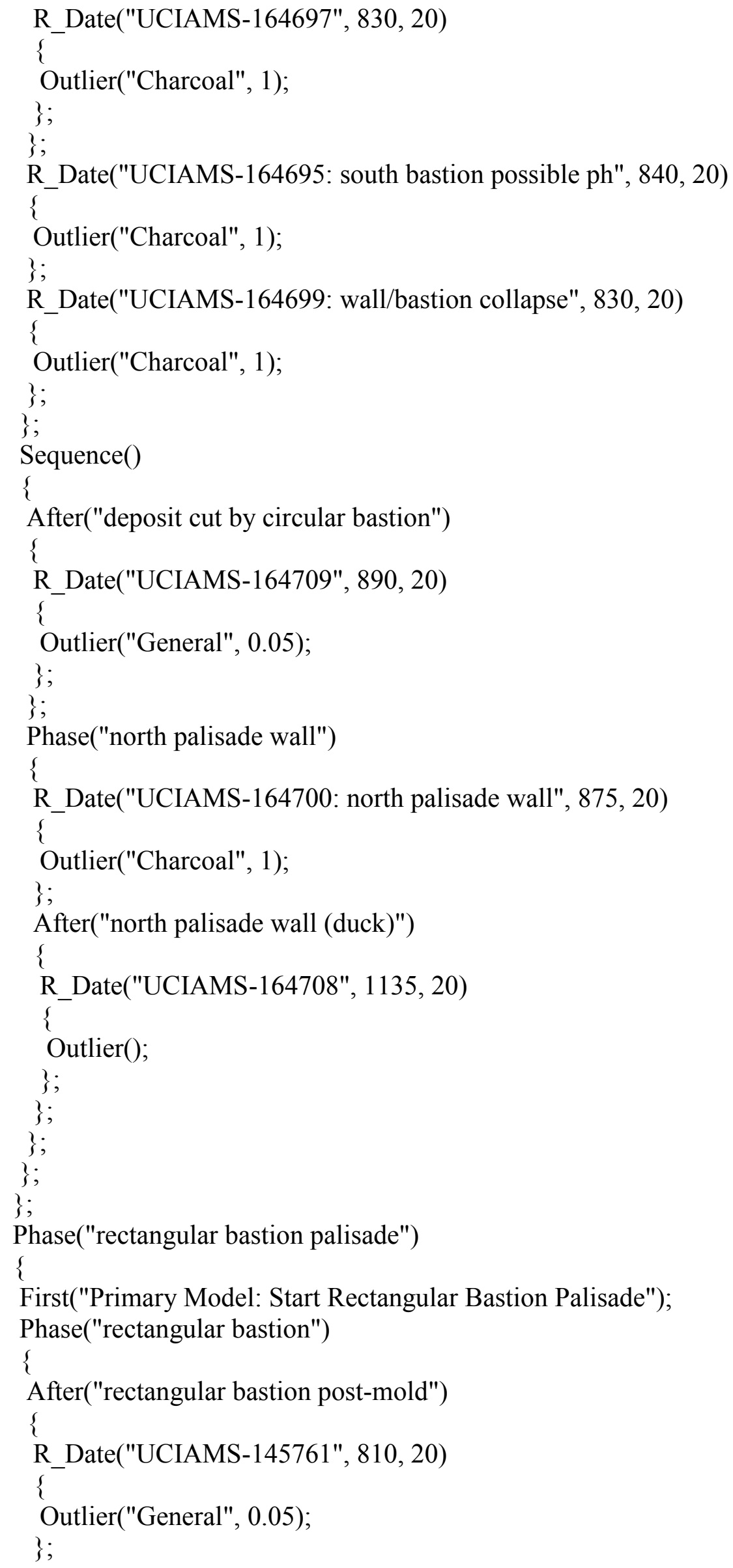




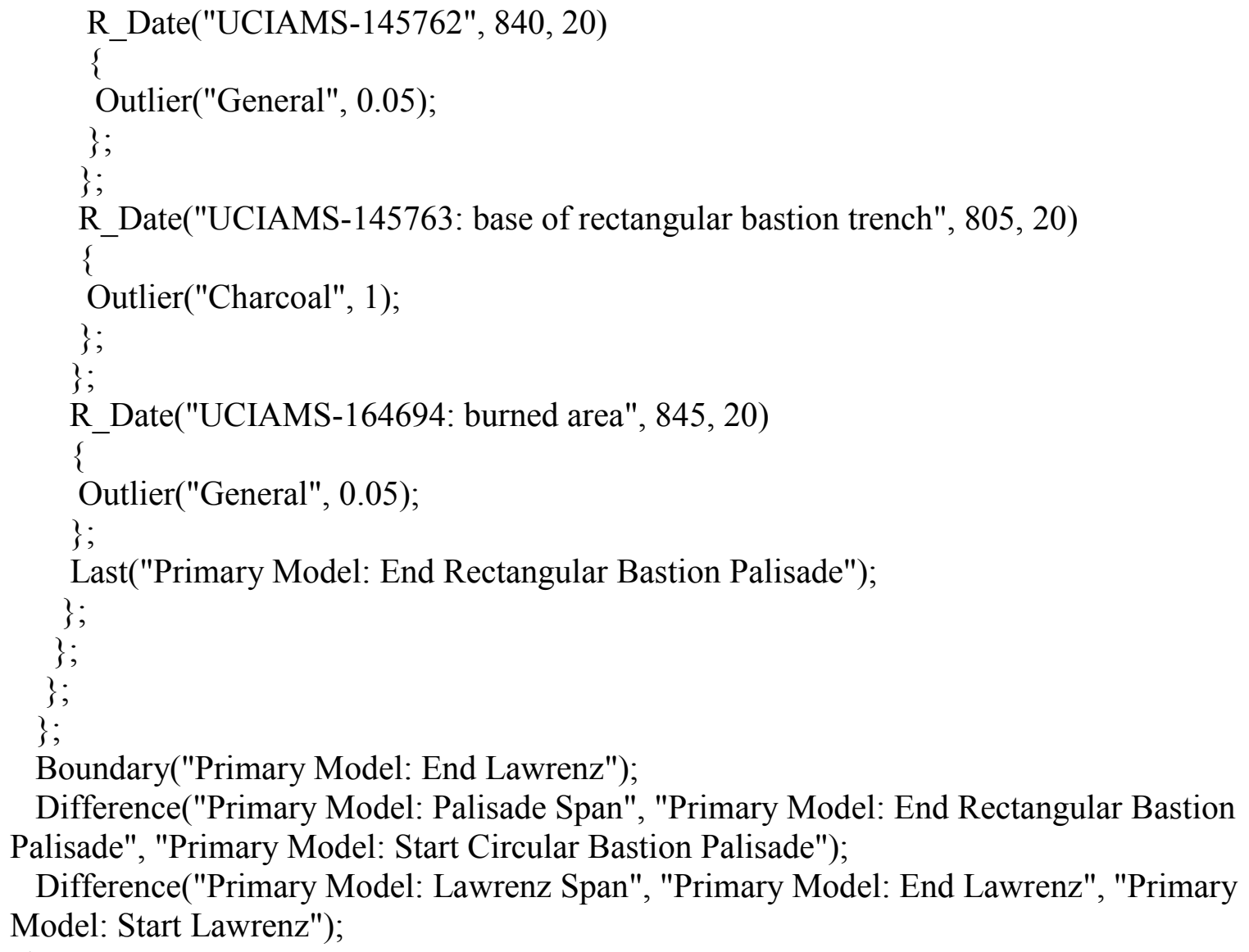

First alternative model:

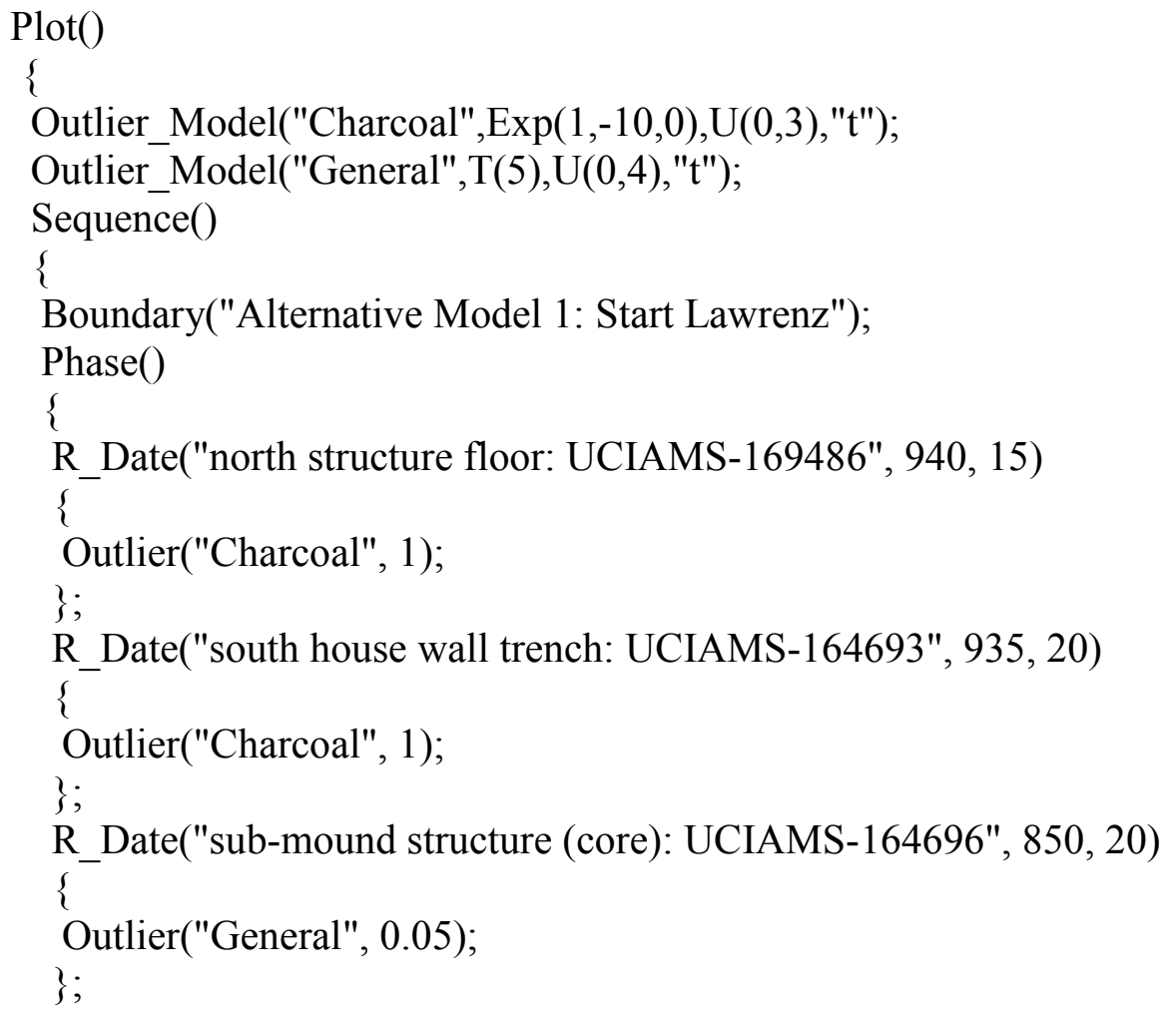




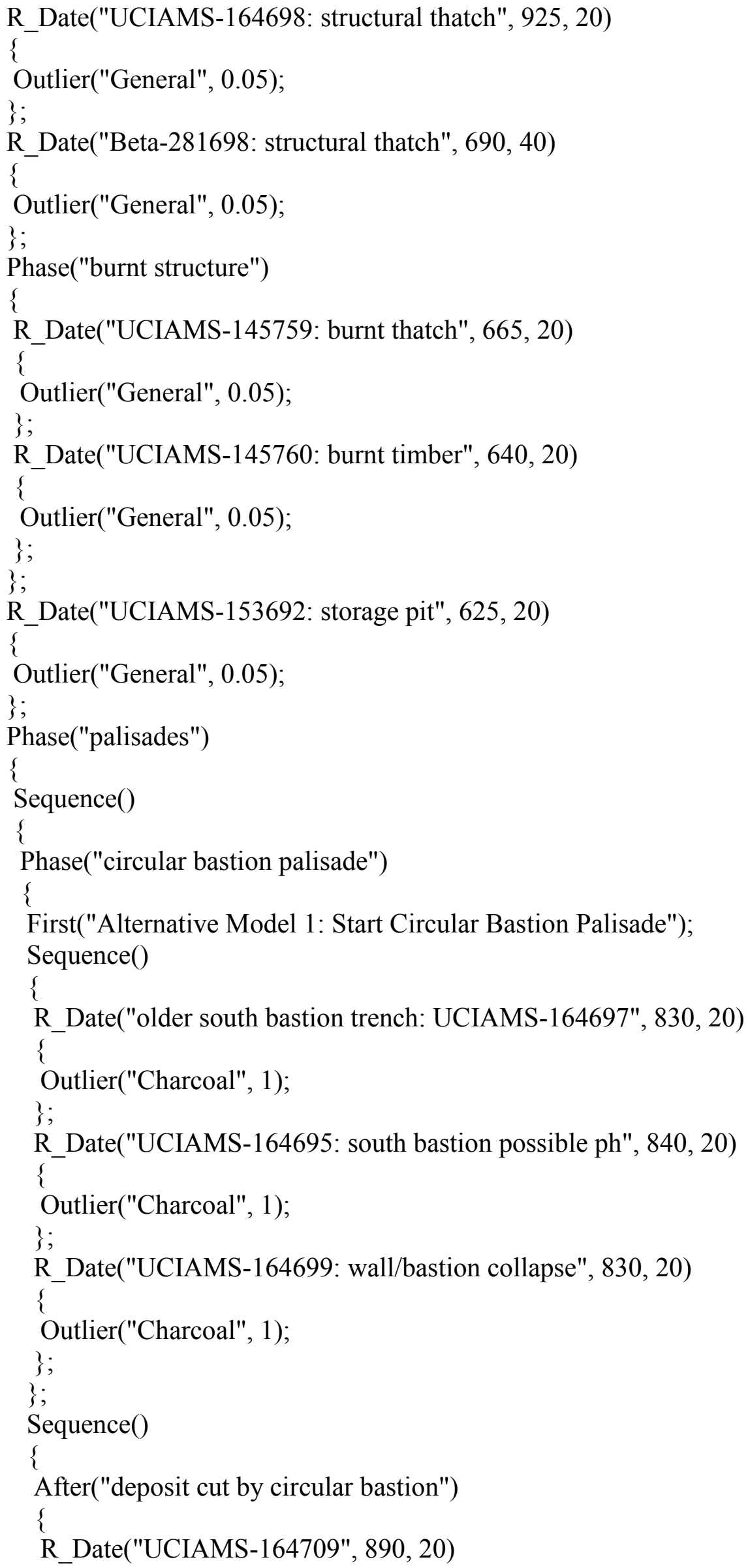




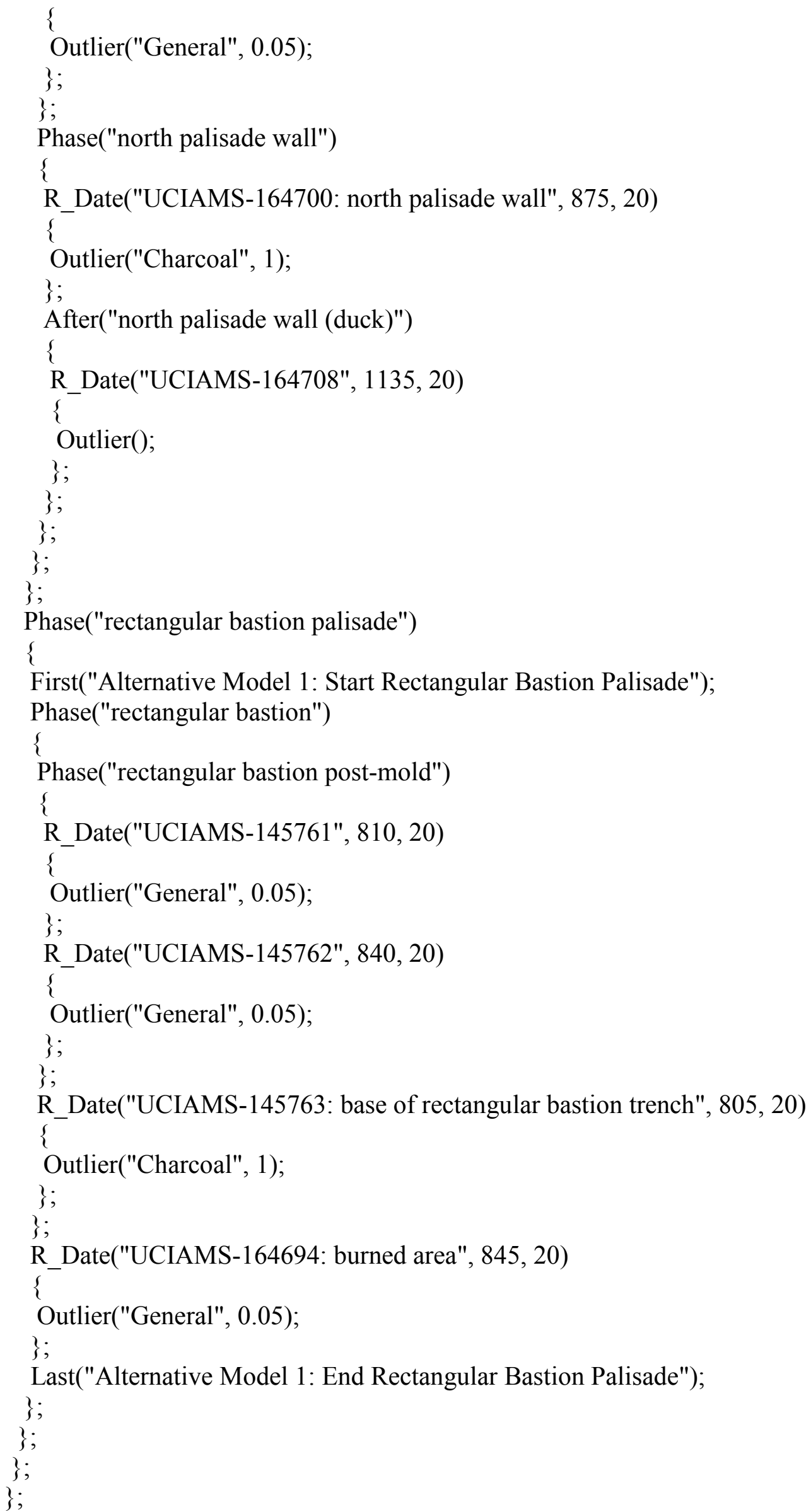


Boundary("Alternative Model 1: End Lawrenz");

Difference("Alternative Model 1: Palisade Span", "Alternative Model 1: End Rectangular Bastion Palisade", "Alternative Model 1: Start Circular Bastion Palisade");

Difference("Alternative Model 1: Lawrenz Span", "Alternative Model 1: End Lawrenz", "Alternative Model 1: Start Lawrenz");

\};

\}

Second alternative model:

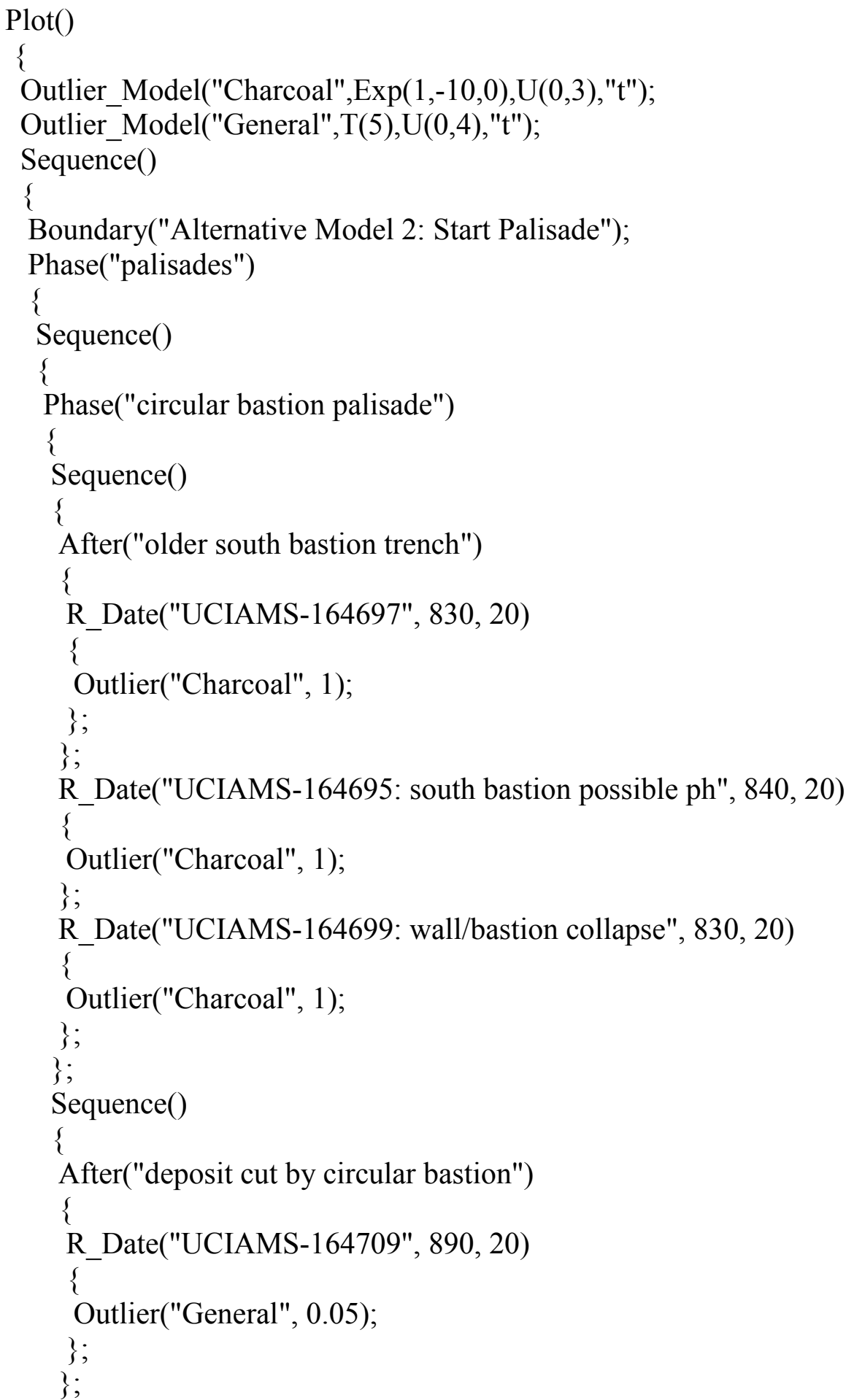




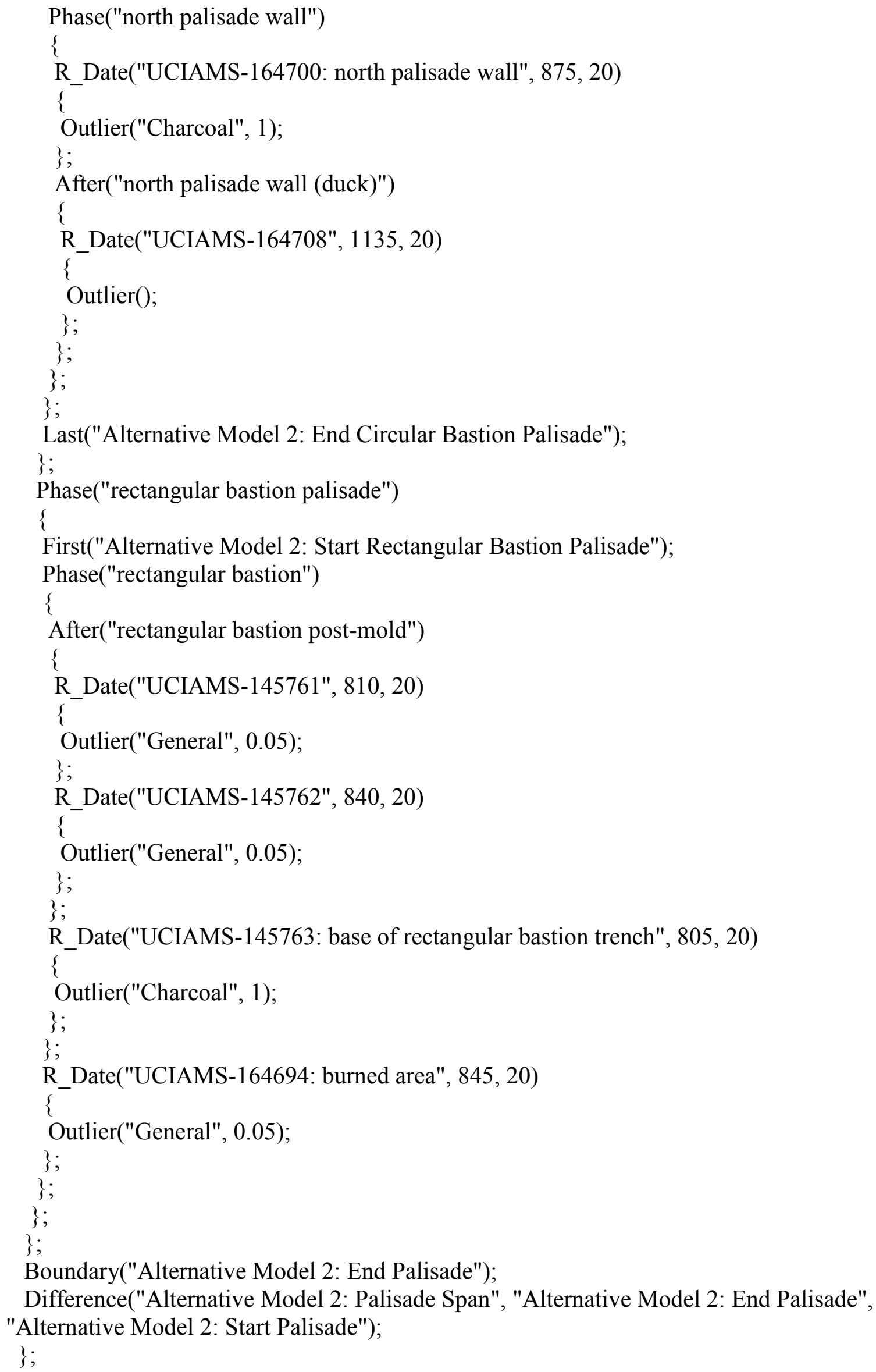

